IZA DP No. 4561

No Child Left Behind:

Universal Child Care and Children's Long-Run Outcomes

Tarjei Havnes

Magne Mogstad

November 2009 


\title{
No Child Left Behind: Universal Child Care and Children's Long-Run Outcomes
}

\author{
Tarjei Havnes \\ University of Oslo
}

\author{
Magne Mogstad \\ Statistics Norway \\ and IZA
}

\section{Discussion Paper No. 4561 \\ November 2009}

\author{
IZA \\ P.O. Box 7240 \\ 53072 Bonn \\ Germany \\ Phone: +49-228-3894-0 \\ Fax: +49-228-3894-180 \\ E-mail: iza@iza.org
}

Any opinions expressed here are those of the author(s) and not those of IZA. Research published in this series may include views on policy, but the institute itself takes no institutional policy positions.

The Institute for the Study of Labor (IZA) in Bonn is a local and virtual international research center and a place of communication between science, politics and business. IZA is an independent nonprofit organization supported by Deutsche Post Foundation. The center is associated with the University of Bonn and offers a stimulating research environment through its international network, workshops and conferences, data service, project support, research visits and doctoral program. IZA engages in (i) original and internationally competitive research in all fields of labor economics, (ii) development of policy concepts, and (iii) dissemination of research results and concepts to the interested public.

IZA Discussion Papers often represent preliminary work and are circulated to encourage discussion. Citation of such a paper should account for its provisional character. A revised version may be available directly from the author. 
IZA Discussion Paper No. 4561

November 2009

\section{ABSTRACT \\ No Child Left Behind: Universal Child Care and Children's Long-Run Outcomes*}

There is a heated debate in the US, Canada and many European countries about introducing universally accessible child care. However, studies on universal child care and child development are scarce and only consider short-run outcomes. We analyze the introduction of universal child care in Norway, addressing the impact on children's long-run outcomes. Our precise and robust difference-in-difference estimates show that child care had strong positive effects on children's educational attainment and labor market participation, and also reduced welfare dependency. Subsample analysis indicates that children with low educated mothers and girls benefit the most from child care.

JEL Classification: J13, H40, 128

Keywords: $\quad$ universal child care, child development, long-run outcomes

Corresponding author:

Magne Mogstad

Research Dept. of Statistics Norway

$\mathrm{Pb} 8131$ Dep

0033 Oslo

Norway

E-mail: magne.mogstad@ssb.no

\footnotetext{
* Thanks to Rolf Aaberge, Michael Baker, Erling Barth, Nabanita Datta Gupta, Jon Fiva, Hilary Hoynes, Torbjørn Hægeland, Halvor Mehlum, Kevin Milligan, Kalle Moene, Mari Rege, Terje Skjerpen, Kjetil Storesletten, Kjetil Telle, Mark Votruba, and a number of seminar and conference participants for useful comments and suggestions. Financial support from the Norwegian Research Council (194347/S20) is gratefully acknowledged. The project is part of the research activities at the ESOP center at the Department of Economics, University of Oslo. ESOP is supported by The Research Council of Norway.
} 


\section{Introduction}

The increased demand for child care associated with the rise of maternal employment is attracting the attention of policy makers and researchers alike. Indeed, access to child care has gone up in many developed countries over the last years (OECD, 2004), and there is a heated debate about a move towards subsidized, universally accessible child care or pre-school, as offered in the Scandinavian countries. For example, the European Union's Presidency formulated in 2002 as a policy goal "to provide childcare by 2010 to at least $90 \%$ of children between 3 years old and the mandatory school age and at least 33\% of children under 3 years of age" (EU, 2002, p. 13). Further, Quebec recently introduced highly subsidized child care, and other Canadian provinces are considering similar policies. In the US, the so-called 'Zero to Five Plan' of US President Obama aims at making states move towards voluntary universal preschool. At the same time, studies on how universal child care affects children's outcomes are scarce, limited to short-run outcomes, and the findings are mixed (Currie, 2001).

This is the first paper that investigates the effects on children's long-run outcomes of a universal child care system. ${ }^{1}$ An advantage of our long-run perspective is that we get round the issues of whether short-run impacts of child care persist, and perhaps are amplified, over time. For example, as pointed out by Baker et al. (2008), their findings of a negative short-run impact of universal child care on children's non-cognitive development, could represent an initial cost of socialization, with little or no long-run consequences. Moreover, if investments in human capital have dynamic complementarities, then even a small learning gain in the short-run may improve the long-run prospects of children considerably (Heckman, 2006). By investigating the effects on adult outcomes of intrinsic importance, we also avoid reliance on test scores and changes in test scores that have no meaningful cardinal scale (Cunha and Heckman, 2008).

We find that the introduction of subsidized, universally accessible child care in Norway had large positive effects on children's adult outcomes, measured in their early 30s. This is true with regard to both education and labor market attachment, as well as welfare dependency. In aggregate terms, the additional 17,500 child care places produced 6,200 years of education.

\footnotetext{
${ }^{1}$ As in Baker et al. (2008), universal child care is taken to mean child care arrangements that are open for everyone; not that all children were in fact using child care.
} 
Exposure to child care raised the chances of completing high school and attending college, in orders of magnitude similar to the black-white race gaps in the US. Consistent with the evidence of higher education and stronger labor market attachment, we also find that children exposed to child care delayed child bearing and family formation as adults. Our subsample analysis indicates that most of the effect on education stems from children with low educated mothers, whereas most of the effect on labor market attachment and earnings relates to girls. This suggests that good access to subsidized child care levels the playing field by increasing intergenerational mobility and closing the gender wage gap.

To elicit causal relationships between child care and children's long-run attainments, we use a difference-in-differences (DD) approach, exploiting a child care reform from late 1975 in Norway. The reform assigned responsibility for child care to local governments and increased federal subsidies, which generated large variation in child care coverage for children 3-6 years old, both across time and between municipalities. ${ }^{2}$ As described in detail below, formal child care in both the pre-reform period and during the expansion was severely rationed, with informal care arrangements (such as friends, relatives, and unlicensed care givers) servicing the excess demand. The reform constituted a shock to the supply of formal child care. The supply shocks were, in general, strongest in municipalities where formal child care was most rationed before the reform. This is likely to be partly because of higher federal subsidy rates for municipalities with low child care coverage prior to the reform, but also due to stronger local political pressure for expansion of formal care in areas where child care was severely rationed.

Our empirical strategy and main results on education are illustrated in Figure I. Panel (a) graphs children's years of education by birth cohort, separately for municipalities where child care expanded a lot (i.e. the treatment group) and municipalities with little or no increase in child care coverage (i.e. the comparison group). The child care expansion started in 1976, affecting children born between 1973 and 1976 with full force. The reform effect per child in the treatment group is given by the change in years of education for 3 to 6 year olds before and after the reform, in the treatment municipalities relative to the comparison municipalities. Panel (b) takes the size of the child care expansion into account, showing the predicted reform

\footnotetext{
${ }^{2}$ Throughout this paper, child care coverage rates refer to formal care, including publicly and privately provided child care institutions as well as licensed care givers, all eligible to subsidies from the government.
} 
effects per child care place based on our DD approach (without controls). Figure I shows a good coherence between the time trends of the groups before the reform, and a striking change in the relative outcomes after the reform. Consistent with this evidence, our baseline DD estimations (with controls) suggest that the reform caused .35 years of education per child care place (cf. Panel (b)), corresponding to an effect of .06 years per child in the treatment municipalities (cf. Panel (a)).

\section{[FIGURE I ABOUT HERE]}

To interpret our findings, we take a close look at a number of possible mechanisms. A crucial point is the relative quality of the counterfactual mode of care. In line with recent studies from several countries (Lundin et al., 2008; Cascio, 2009; Havnes and Mogstad, 2009), our results indicate that the new subsidized child care crowds out informal care arrangements, with almost no net increase in total care use and maternal labor supply. This implies that our estimates should be interpreted as reflecting a shift from informal care of presumably inferior quality, rather than from parental care. The fact that the reform had little, if any, effect on maternal employment also means that it is unlikely that increased family income is the driving factor behind the positive effects. Nor is an increase in the quality of formal child care a likely explanation. Below we offer some evidence indicating that the quality of formal child care in the treatment area was not increasing relative to the rest of Norway.

Having access to high-quality panel data from administrative registers covering the entire resident population and all licensed care givers in Norway, we are able to pay close attention to the concern that the implementation of the reform could be endogenous to children's potential outcomes; Children living in municipalities with good access to child care may be inherently different and would have different outcomes in any case. The DD approach controls for unobserved permanent differences between children born in different years as well as between children from different areas. Our estimates are also robust to inclusion and exclusion of a large set of controls capturing important child and parental characteristics, as well as municipality-specific fixed effects.

To further increase our confidence in the empirical strategy, we run a battery of specification checks. In particular, we address the two identification assumptions underlying DD 
estimation from policy changes creating state-time variation, as emphasized by Besley and Case (2000). These assumptions are that the time-effects must be identical between the treatment and comparison group, and that the composition of the groups must remain the same, implying a common time trend between the treatment and comparison group in the absence of the reform. The common trend assumption is supported by the fact that we find no effects of placebo-reforms, pretending that the child care expansion took place in the pre-reform period. Nevertheless, to allow treatment and comparison areas to follow different secular trends, we add municipality-specific time trends. It's heartening to find that our estimates are, in general, quite similar when including these trends. To make sure that our results are not driven by secular changes between urban and rural areas coinciding with the child care reform, we drop the three big cities from our analysis; the estimates barely move. Motivated by Crump et al.'s (2009) propensity score approach for systematic sample selection as a precursor to the regression estimation, we exclude children from municipalities with very high or very low predicted change in child care coverage following the reform. The estimates from this subsample confirm the picture of strong positive child care effects. Further, the results are robust to inclusion of family-specific effects, limiting the comparison to siblings before and after the reform that experience different exposure to child care. We also take several steps to make sure that selective migration of families into treatment and comparison municipalities is not driving our results. Finally, it should be noted that identification from a common trend assumption depends only on what would have happened in the absence of the reform: If, for instance, child care expanded most in municipalities where it was most effective in promoting child development, then this would not pose a threat to identification of the treatment effect on the treated.

We might still worry about confounding our estimated child care effects with other reforms or changes taking place in the same period. As discussed below, we have found no significant policy changes or breaks in trends that could be of concern for our estimations. Importantly, there were no significant changes in the Norwegian educational policies affecting the cohorts of children we consider. On the contrary, Norway was known for its unified public school system based on a common national curriculum, rooted in a principle of equal rights to high-quality education, regardless of social and economic background or residency. This is mirrored in very 
similar expenditure levels per student across municipalities and virtually no private schools.

The paper proceeds by first discussing our study in relation to previous research on child care and child development, before Section III describes the 1975 reform and the succeeding expansion in child care. Section IV outlines the empirical strategies and Section V presents our data. Section VI discusses our main results, whereas Section VII reports the specification checks. Section VIII investigates heterogenous responses, before Section IX focuses on the mechanisms behind our findings and Section X concludes.

\section{Child care and child development}

Recent research from a number of fields suggests that investments in early childhood have high returns, especially for disadvantaged children (Knudsen et al., 2006). Studies in neuroscience and development psychology indicates that learning is easier in early childhood than later in life (Shonkoff and Phillips, 2000). In the economics literature, Becker (1964) points out that the returns to investments in early childhood are likely to be relatively high, simply because of the long time to reap the rewards. Taking this argument one step further, Carneiro and Heckman (2004) argue that investments in human capital have dynamic complementarities, implying that learning begets learning.

On this background, Currie (2001) suggests that governments should aim to equalize initial endowments through early childhood development, rather than compensate for differences in outcomes later in life. The role of governments in facilitating child development is particularly important, both from positions on equity and efficiency, if families under-invest in early childhood due to market failures such as liquidity constraints, information failures, and externalities (Gaviria, 2002).

Child care institutions are important arenas for child development, and expanding child care coverage is an explicit goal in many countries. A number of studies show that early childhood educational programs can generate learning gains in the short-run and, in many cases, improve the long-run prospects of children from poor families. ${ }^{3}$ While the results from these studies are

\footnotetext{
${ }^{3}$ The Perry Preschool and Abecedarian programs are commonly cited examples of how high-quality preschool services can improve the lives of disadvantaged children. See Barnett (1995) and Karoly et al. (2005) for surveys
} 
encouraging, the programs evaluated were unusually intensive and involved small numbers of particularly disadvantaged children from a few cities in the US. A major concern is therefore that this evidence may tell us little about the effects of universal child care systems offered to the entire population (Baker et al., 2008). Nonetheless, it has fuelled an increasing interest in universal provision of child care as a means of advancing child development and improving children's long-run outcomes.

Our paper contributes to a small but rapidly growing literature on the effects of universal child care programs. So far, the evidence is limited to short-run outcomes and the findings are mixed. Loeb et al. (2007), for instance, find that pre-primary education in the US is associated with improved reading and mathematics skills at primary school entry. However, Magnuson et al. (2007) suggest that these effects dissipate for most children by the end of first grade. Positive effects of child care on children's short-run outcomes are also found by Gormley and Gayer (2005), Fitzpatrick (2008), Melhuish et al. (2008), and Berlinski et al. (2008, 2009). On the other hand, Baker et al. (2008) analyze the introduction of subsidized, universally accessible child care in Quebec, finding no impact on children's cognitive skills but substantial negative effects on children's non-cognitive development. Bernal (2009) suggests that having a mother that works full-time and uses child care has a small, negative effect on ability test scores. These negative effects echo the results in Herbst and Tekin (2008), while Datta Gupta and Simonsen (2007) find that compared to home care, being enrolled in preschool does not lead to significant difference in child non-cognitive outcomes.

While the evidence on short-run effects of universal child care programs is of interest, a crucial question is whether these effects persist, and perhaps are amplified, over time. As noted by Baker et al. (2008), negative short-run effects could reflect that children have difficulties in their first interactions with other children. In that case, child care attendance may expose children to these costs earlier on, so that they are better prepared for attending school. In addition, evidence from early intervention programs targeting particularly disadvantaged children suggests that even though the short-run gains in test-scores tended to dissipate over time, there were strong and persistent impacts on long-run outcomes (Heckman et al., 2006). This paper of the literature. 
circumvents these issues by investigating the impact of universal child care on adult outcomes that are of intrinsic importance. By doing so, we also avoid reliance on test scores and changes in test scores that have no meaningful cardinal scale (see Cunha and Heckman, 2008).

\section{Background}

In the post-WWII years in Norway, the gradual entry on the labor market of particularly married women with children, caused growing demand for out-of-home child care. In a survey from 1968, when child care coverage was less than five percent, about 35 percent of mothers with 3 to 6 year olds stated demand for formal child care (NOU, 1972). In the same survey, only 34 percent of the latter group of respondents stated that they were in fact using out-of-home child care on a regular basis. Out of these, just 14 percent were in formal child care, while more than 85 percent were using informal arrangements. ${ }^{4}$

The severe rationing of formal child care acted as a background for political progress towards public funding of child care. ${ }^{5}$ In the early 1950s, grants and subsidized loans were temporarily made available for construction and refurbishment of child care institutions, and their operation was regulated by law in 1954. Federal subsidies to formal child care were assigned a permanent post on the national budget in 1962, and increased over the subsequent ten years from a modest USD 50 per child care place to a maximum of more than USD 1,200 annually. ${ }^{6}$ The child care subsidies were contingent on a federally determined maximum price to be paid by the parents, which in 1972 was about USD 215 per month for full time care (NOU, 1972).

In 1972, the Norwegian government presented the Kindergarten White Paper (NOU, 1972), proposing radical changes in public child care policies. To (i) create positive arenas for child development, (ii) free labor market reserves among mothers, and (iii) lessen the burden on parents and relieve stress in the home, it was argued that child care should be made universally available. This marked a strong shift in child care policies, from focusing on children with special needs (in particular disabled children and children from disadvantaged families) to a

\footnotetext{
${ }^{4}$ Relatives stand out as the largest group of informal care givers at 35 percent, followed by play parks at 20 percent, maids at 14 percent, other unlicensed care givers at 10 percent, and finally more irregular arrangements (such as neighbors and friends) at 7 percent (NOU, 1972).

${ }^{5}$ See Leira (1992, ch. 4) for a detailed survey of the history of Norwegian child care policies since WWII.

${ }^{6}$ Throughout this paper, all monetary figures are in US dollars, and fixed at 2006-level (NOK/USD = 6.5).
} 
focus on a child care system offered to the entire population.

In June 1975, The Kindergarten Act was passed by the Norwegian parliament with broad bipartisan political support. It assigned the responsibility for child care to local municipalities, but included federal provisions on educational content, group size, staff skill composition, and physical environment. By increasing the level of federal subsidies for both running costs in general and investment costs for newly established institutions, the government aimed at quadrupling the number of child care places to reach a total of 100,000 places by $1981 .^{7}$

In the years following the reform, the child care expansion was progressively rolled out at a strong pace, with federal funding more than doubling from USD 34.9 million in 1975 to 85.8 million in 1976, before reaching 107.3 million in $1977 .{ }^{8}$ This implied an increase in the federal coverage of running costs from about $10 \%$ in 1973 to $17,6 \%$ in 1976 , and further to $30 \%$ in 1977. From 1976, newly established child care places received additional federal funds for a period of five years: Municipalities with a child care coverage rate below $10 \%$ were awarded $60 \%$ more subsidies, whereas other municipalities were awarded $40 \%$ extra.

Altogether, the reform constituted a substantial positive shock to the supply of formal child care. In succeeding years, the previously slow expansion in subsidized child care accelerated rapidly. From a total coverage rate of less than 10 percent for 3 to 6 year olds in 1975, coverage had shot up above 28 percent by 1979. Over the period, a total of almost 38,000 child care places were established, more than a doubling from the 1975-level. By contrast, there was almost no child care coverage for 1 and 2 year olds during this period. Figure II draws child care coverage rates in Norway from 1960 to 1996 for 3 to 6 year olds. As is apparent from the figure, there has been strong growth in child care coverage rates since 1975, particularly in the early years.

\section{[FIGURE II ABOUT HERE]}

Table I reports child care institutions by owner biannually from 1975 through 1981, and shows the strong growth in municipal and cooperative child care centers. Over the period, the share

\footnotetext{
${ }^{7}$ In addition, the price-setting was delegated to local municipalities, abolishing the federally determined maximum parental price for child care subsidies. However, Gulbrandsen et al. (1981) report survey data suggesting that the maximum price to be paid by the parents actually changed little in the years following the reform, and formal child care remained rationed well into the $90 \mathrm{~s}$

${ }^{8}$ Source: National budgets 1975/76 through 1978/79.
} 
of private centers decreased from 28 to 20 percent, driven almost entirely by a decline in the share of centers run by private organizations.

\section{[TABLE I ABOUT HERE]}

We might worry about confounding the estimated child care effects with other reforms or changes taking place in the same period. However, we have found no significant reforms or breaks in trends that could be of concern for our estimations. An extension in maternity leave implemented in 1977 did not affect the children in our sample directly, but could potentially influence family size, which could in turn matter for child development. However, the reform was nationwide, and should be controlled for by cohort fixed-effects. In addition, our rich set of controls may pick up potentially remaining effects of this policy change.

Importantly, there were no significant changes in the Norwegian educational policies affecting the cohorts of children we consider, born $1967-1976 .{ }^{9}$ At the end of WWII, the Norwegian school system was based on a seven-year compulsory education free of charge for all children from the age of 7, before splitting into vocational and academic tracks of various length. There were two major educational reform periods in Norway after WWII; The first reform period was in the late 1960s and early 1970s, whereas the second reform period was in the 1990s.

In the first reform period, Norway cemented its unified school system, rooted in a principle of equal rights to high-quality education, regardless of social and economic background or residency. This manifested itself in a major school reform in 1969, expanding compulsory education to nine years. At the same time, the curriculum was standardized to ensure that federally determined educational standards were met nationwide. The collective objectives and principles for teaching were laid down in this national curriculum. In 1974, the various post-compulsory school tracks were merged into a three-year high school system of academic or vocational studies. In this unified school system, there was no room for different types of schools existing in parallel, with the result that there were almost no private schools; For example, the number of pupils in private schools comprised only half a percent of the total number of children of compulsory school age in 1970. Moreover, the expenditure levels per

\footnotetext{
${ }^{9}$ See Telhaug et al. (2006) and Volckmar (2008) for an in-depth discussion of the Norwegian educational system since the 1950 s.
} 
student across municipalities were very similar. The policy changes in the first reform period affect all the cohorts of children included in our analysis.

After two decades with only minor changes in the educational system, a reform in 1994 granted the statutory right to three years of high school for all youth between 16 and 19 years, starting with children born in 1978. Moreover, the curriculum was altered so that all high school students, in academic tracks or vocational tracks, followed the same basic courses in the first year. These policy changes did not affect the cohorts of children included in our analysis.

\section{Identification strategy}

To estimate the effect of universal child care on children's outcomes we follow the previous literature closely in applying a DD approach, exploiting that the supply shocks to formal child care were larger in some areas than others. Below, we will first describe our main empirical strategy, before discussing alternative specifications addressing potential threats to identification.

Main empirical strategy. Our main empirical strategy is the following: We compare the adult outcome of interest for 3 to 6 year olds before and after the reform, from municipalities where child care expanded a lot (i.e. the treatment group) and municipalities with little or no increase in child care coverage (i.e. the comparison group).

The child care expansion started in 1976, affecting the post-reform cohorts born 1973-1976 with full force, and to a lesser extent the phase-in cohorts born 1970-1972. The pre-reform cohorts consist of children born in the period 1967-1969. We consider the period 1976-1979 as the child care expansion period. Starting in 1976 gives the municipalities some time to plan and react to the policy change. Also, 1976-1979 was the period with the largest growth in child care coverage. In the robustness analysis, we make sure that our results are robust to changes in the exact choice of expansion period.

To define the treatment and comparison group, we order the municipalities according to the percentage point increase in child care coverage rates from 1976 to 1979 . We then separate the sample at the median, letting the upper half constitute the treatment municipalities and 
the lower half the comparison municipalities. Figure III displays child care coverage before and after the 1975 reform in treatment and comparison municipalities (weighted by population size). The graphs move almost in parallel before the reform, while the child care coverage of the treatment municipalities kinks heavily after the reform. This illustrates that our study compares municipalities that differ distinctly in terms of changes in child care coverage within a narrow time frame. In the robustness analysis, we take several steps to make sure that our results are robust to the exact child care coverage cut-off, defining the treatment and comparison municipalities.

\section{[FIGURE III ABOUT HERE]}

Our main regression model, estimated by OLS over the sample of children born during the period 1967-1976, can be defined as

$$
Y_{i j t}=\psi_{t}+\gamma_{1} \text { Treat }_{i}+\gamma_{2}\left(\text { Treat }_{i} \cdot \text { Phasein }_{t}\right)+\theta\left(\text { Treat }_{i} \cdot \text { Post }_{t}\right)+X_{i j t}^{\prime} \beta+\epsilon_{i j t}
$$

where $Y$ is the outcome of interest measured in 2006, $i$ indexes child, $j$ indexes family, and $t$ indexes the year the child turns 3 years old. The vector of covariates $X$ includes dummy variables for parent's birth cohort, their education when the child is 2 years old, their age at first birth, the number of older siblings (also capturing birth order) and relocation between municipalities within treatment/comparison area, the child's sex and immigrant status, as well as municipality-specific fixed effects. The error term $\epsilon_{i j t}$ is clustered on the child's mother, allowing for dependence in the residuals of siblings. The dummy variable Treat $_{i}$ is equal to 1 if child $i$ lives in the treatment area, Phasein ${ }_{t}$ and Post $_{t}$ are dummy variables equal to 1 when $t \in[1973,1975]$ and $t \in[1976,1979]$ respectively, while $\psi_{t}$ are cohort-specific fixed effects. ${ }^{10}$

The parameter of interest, $\theta$, captures the average causal effect on children who reside in the treatment area in the post-reform period, of additional child care slots following the reform in

\footnotetext{
${ }^{10}$ Some of the outcomes of interest are limited dependent variables. In these cases, our linear probability model will be the best least-squares approximation of the true conditional expectation function. As noted by Angrist (2001), if there are no covariates or they are discrete, as in our case, linear models are no less appropriate for limited dependent variables than for other types of dependent variables. In any case, we have checked that our results are robust to alternative approximations of the conditional expectation function, estimating Logit and Probit models.
} 
the treatment municipalities compared to the comparison municipalities. There are two types of averaging underlying this average causal effect. First, there is averaging over the impacts on children from different municipalities in the treatment area. And second, there is averaging across the marginal effects of the additional child care slots. Like in Baker et al. (2008), we will interpret $\theta$ as an intention-to-treat effect (ITT), since our regression model estimates the reduced form impacts on all children from post-reform cohorts who reside in the treatment area. An advantage of the ITT parameter is that it captures the full reform impact of changes in both formal and informal care arrangements, as well as any peer effects on children who were not attending child care. However, since this parameter averages the reform effects over all children in the municipality, it reflects poorly the size of the child care expansion. To arrive at the treatment-on-the-treated (TT) effect, we follow Baker et al. and scale the ITT parameter with the probability of treatment. Specifically, we divide the ITT parameter with the increase in child care coverage following the reform in the treatment group relative to the comparison group. For example, $T T=I T T / 0.1785$ in our baseline specification. The TT parameter gives us the effect of child care exposure - per child care place - on children born in post-reform cohorts who reside in the treatment area. In our main results, we report both the ITT and the TT estimates.

The DD approach controls for unobserved differences between children born in different years as well as between children from treatment and comparison municipalities. The identifying assumption is that the change in the outcome of interest for 3 to 6 year olds before and after the reform would have been the same in the treatment municipalities as in the comparison municipalities, in the absence of the reform. If, for instance, child care expanded most in municipalities where it was most effective in promoting child development, then this would not pose a threat to identification of the ITT or TT parameters. However, a concern could be that the time trend in children's outcomes differs by, say, parent's education, while there are systematic differences in parental education between treatment and comparison municipalities. To address such concerns for selection bias, we estimate equation (1) with and without the set of controls $X$.

Because we also control for municipality-specific fixed effects, it is not necessary that the 
child care expansion is unrelated to municipality characteristics. It is useful, however, to understand the determinants of the expansion across municipalities. In Section V, we investigate this closely, finding that the characteristics of treatment and comparison municipalities are fairly similar in terms of political and demographic composition as well as local government expenditure and income. A notable exception is that the expansion was strongest in municipalities with the lowest ratio of formal child care coverage to employment rate of mothers with children in child care age. This conforms well to intuition, since federal subsidy rates were higher for municipalities with low child care coverage prior to the reform, but also because the local political pressure for expansion of formal care is likely to be stronger in areas where child care was severely rationed.

Although municipality-specific fixed effects picks up the direct effects of pre-determined factors of the municipalities, like differences in rationing of formal child care prior to the reform, we may worry about the determinants of the child care expansion being systematically related to underlying trends in child outcome. And even though the DD approach controls for unobserved differences both between children born in different years as well as between children from treatment and comparison municipalities, there could be changes over time in the differences in the unobservable characteristics of children from the two groups. As always in policy evaluation using non-experimental data we cannot completely guard against such omitted variables bias. Yet to increase the confidence in our identification strategy, we run a battery of specification checks.

Alternative specifications. To investigate the assumption of a common time trend between the treatment and comparison group in the absence of the reform, we perform placebo-reforms, pretending that the child care expansion took place in the pre-reform period. To allow treatment and comparison areas to follow different trends due to, say, differences in child care rationing prior the reform, we further estimate equation (1) with municipality-specific time trends. To make sure that our results are not driven by secular changes between urban and rural areas coinciding with the child care reform, we drop the three big cities from our analysis. Motivated by Crump et al.'s (2009) use of propensity score for systematic sample selection as a precursor to the regression estimation, we exclude children from municipalities with very high or very low 
predicted change in child care coverage following the reform. The idea is that the assumption of a common time trend may be more plausible if there is stronger overlap in the covariate distribution between the treatment and comparison municipalities. Unlike previous studies using a DD approach to examine universal child care and children's outcomes, we also add family-specific fixed effects, limiting the comparison to siblings before and after the reform that have the same family background but experience different exposure to child care. In addition, we take several steps to address the concern for selective migration of families into treatment and comparison municipalities.

As discussed above, our DD estimator captures the average causal effect of additional child care slots following the reform in the treatment municipalities relative to the comparison municipalities. Figure A1 reported in Appendix A draws histograms of the distributions of municipalities by child care coverage rate in 1976 and 1979. It shows a fairly good coherence in child care coverage rates between the treatment and comparison municipalities before the reform, and a striking difference after the reform. It is also evident that the treatment intensity varies within the two groups of municipalities. In the robustness analysis, we therefore consider variations in the treatment intensity by changing the child care coverage cut-off defining the treatment and comparison municipalities. In addition, we follow Berlinski et al. (2009) in regressing child outcome on child care coverage rate in each municipality, controlling for cohort and municipality fixed-effects, as well as a set of controls. This regression model, estimated by OLS over the sample of children born during the period 1967-1976, can be defined as

$$
Y_{i j t}=\delta_{t}+\zeta C C_{i t}+X_{i j t}^{\prime} \varphi+\epsilon_{i j t}
$$

where $C C_{i t}$ is the average child care rate in the municipality of child $i$ from the year $t$ when the child turns 3 years old until, but not including, year $t+4$ when he or she turns 7 and starts primary school. 


\section{Data}

Our data is based on administrative registers from Statistics Norway covering the entire resident population of Norway from 1967-2006. The data contains unique individual identifiers that allow us to match parents to their children. As we observe each child's date of birth, we are able to construct birth cohort indicators for every child in each family. The family and demographic files are merged through the unique child identifier with a wide range of his or her adult outcomes measured in 2006, including educational attainment, earnings, welfare dependency, and household type and composition. The information on educational attainment is based on annual reports from Norwegian educational establishments, whereas the income and welfare data are collected from tax records and other administrative registers. The household information is from the Central Population Register, which is updated annually by the local population registries and verified by the Norwegian Tax Authority.

Importantly, we also have administrative register data on all formal child care institutions and their location from 1972, reported directly from the institutions themselves to Statistics Norway. All licensed care givers are required to report annually the number of children in child care by age. Merging this data with the demographic files containing information about the total number of children according to age and residency, we construct a time series of annual child care coverage (by age of child) in each of the 414 municipalities. The coverage and reliability of Norwegian register data is considered to be exceptional, as is documented by the fact that they received the highest rating in a data quality assessment conducted by Atkinson et al. (1995).

We start with the entire population of children born during the period 1967-1976, who were alive and resident in Norway in 2006. This sample consists of 575,300 children, spanning these 10 birth cohorts. The choice of cohorts serves three purposes. Since our outcomes are measured in 2006, the treated children are between 30 and 33 years old at the time of measurement, which should be suitable when assessing children's adult outcomes (see e.g. Haider and Solon, 2006). Second, since treatment and comparison groups are defined by the expansion in child care from 1976 to 1979 , the regional and time variation between the two groups breaks down as we move away from 1979. Indeed, the coverage rates do converge slowly after 1979. Finally, to ensure 
comparability of children before and after the reform, we do not want the cohorts to be too far apart.

We restrict the sample to children whose mothers were married at the end of 1975, which makes up about 92 percent of the above sample. The reason for this choice is that our family data does not allow us to distinguish between cohabitants and single parents in these years. As parents' family formation may be endogenous to the reform, we only condition on prereform marital status. To avoid migration induced by the child care reform, we also exclude children from families that move between treatment and comparison municipalities during the expansion period, which makes up less than 5 percent of the above sample. Finally, we exclude a handful of children whose mother had a birth before she was aged 16 or after she was 49 . Rather than dropping observations where information on parents' education is missing, we include a separate category for missing values. The education of the parents is measured when the child is 2 years old. The number of older siblings relates to children born to each mother. The final sample used in the estimations consists of 499,026 children from 318,367 families, which makes up about 87 percent of the children from each cohort.

When interpreting our results, it is necessary to have these sample selection criteria in mind. We focus on children of married mothers. Thus, our results do not speak to the literature on early childhood educational programs targeting special groups like children of single mothers, but these are not the central focus of the current policy debate. To arrive at the TT parameter, we assume equal take up of child care among children included in and excluded from our sample. In particular, we assume that children of single and cohabitant parents are as likely to take up the new child care places as children of married mothers. If the take-up rate is higher (lower) for children excluded from our sample, the TT parameter will be downward (upward) biased. Unfortunately, we do not have data on child care use by child and parental characteristics.

The adult outcomes are defined as follows. Years of education of the child is the number of completed years of education in 2006. Attended college means having at least 13 years of education, while high-school dropout is having no more than 11 years of education. To measure labor market attachment and welfare dependency, we rely on the basic amount thresholds of the Norwegian Social Insurance Scheme (used to define labor market status, determining eligibility 
for unemployment benefits as well as disability and old age pension). In 2006, one basic amount is about USD 10,500. To account for non-linearities in the effects on earnings, we use four different earnings measures. An individual is defined as a low earner if he or she earns less than two basic amounts (also including zero earnings), whereas an average earner has at least four basic amounts in earnings. High and top earners are defined as having at least eight and twelve basic amounts, respectively. Our earnings measure includes wages and income from self-employment. A person is defined as being on welfare if he or she receives more than one basic amount in public cash transfers. Finally, individuals are single with no child if they are neither married/cohabitant or single parent. A person is defined as a single parent if he or she is single and the primary care giver to a child, whereas individuals are defined as parent if they are in a couple with children or are single parents.

Descriptive statistics. Table II shows means for our dependent variables. As is evident from the table, there are modest or no differences in the outcomes of the treatment and comparison group for pre-reform cohorts. The phase-in cohorts diverge slightly in most variables, while post-reform cohorts show distinct differences. In a DD framework, this pattern is suggestive of significant effects of child care on children's outcomes. Figures A2-A4 in Appendix B graph the means of all outcomes by child cohort in treatment and comparison municipalities. We see a good coherence between the time trends of the groups before the reform, and a substantial change in the relative outcomes after the reform.

\section{[TABLE II ABOUT HERE]}

Our DD approach identifies the effects of child care by comparing the change in the outcome of interest before and after the reform of children residing in treatment and comparison areas. Substantial changes over time in the differences in the observable characteristics of the two groups may suggest unobserved compositional changes, calling our empirical strategy into question. Table III shows means of our control variables for characteristics of the child and the parents. It turns out that the treatment and comparison groups have fairly similar characteristics. More importantly, there appears to be small changes over time in the relative characteristics of the two groups. Table A1 in the Appendix A shows DD estimates of equation (1), where 
we have replaced the dependent variable with each control variable. With the exception of relocation between municipalities within the treatment/comparison area, the results show small - and mostly insignificant - differences over time in the characteristics of children residing in the treatment and comparison areas. If anything, the negative estimates for parents' education may contribute to downward bias in the estimated child care effects, if parental education spills over to child outcomes. We have also performed all estimations excluding all families that relocate between municipalities within the treatment/comparison area. These estimations yield very similar results.

A concern in applying linear regressions is lack of overlap in the covariate distribution. As emphasized by Imbens and Wooldridge (2009), this can be assessed by the (scale-invariant) normalized difference measure. For each covariate, the normalized difference is defined as the difference in averages by treatment status, scaled by the square root of the sum of variances. Imbens and Wooldridge suggest as a rule of thumb that linear regression methods tend to be sensitive to the functional form assumption if the normalized difference exceeds one quarter. Table III displays normalized differences for our controls in curly brackets, indicating that lack of overlap should be of little concern for the estimated effects.

\section{[TABLE III ABOUT HERE]}

As discussed above, because we control for municipality-specific fixed effects, it is not necessary that the child care expansion is unrelated to municipality characteristics. However, if determinants of the expansion are systematically related to underlying trends in children's potential outcomes, we may be worried about differences in the characteristics of treatment and comparison municipalities. For example, if expansive municipalities are aiming at counteracting a particularly negative trend in child development, or if they are taking some of the child care investment funds from other policies affecting child development, then our estimates will be biased downwards. Similarly, if municipalities expand in order to stimulate a particularly positive trend or if expansive municipalities also invest in other means of stimulating child development, then our estimates will be biased upwards. It is useful, therefore, to understand the determinants of the expansion across municipalities. 
In Appendix A, we include a map of Norway, marking the treatment and comparison municipalities in Figure A2. The map shows that the municipalities are reasonably well spread out, covering urban and rural municipalities. In our baseline specification, five of the ten largest cities - by the number of children in our sample - are defined as treatment municipalities (Oslo, Bergen, Stavanger, Bærum and Fredrikstad), while the others are defined as comparison municipalities (Trondheim, Kristiansand, Troms $\emptyset$, Skien and Drammen). Further, Table A2 in Appendix A display characteristics of the municipalities in the treatment and comparison area. There appears to be no substantial differences in terms of local government expenditure per capita, in total or on primary school in particular. This is most likely because of strict federal provisions for minimum standards of different local public services, and considerable ear-marked grants-in-aid from the central government. The same holds for local government income, consisting largely of grants-in-aid from the central government, local income taxes, and user fees. This comes as no surprise, as the federal government determines the tax rate and the tax base of the income tax. Also, the federal government used equalization transfers to redistribute income from rich to poor municipalities, such that local differences in revenues are largely offset (Løken, 2009). Interestingly, there are no noticeable differences in the share of female voters between the municipalities of the treatment and comparison area, nor is there significant disparity in the socialist shares of voters. This conforms well to the fact that there was broad bipartisan support for child care expansion in Norway in the 1970s. Further, we do not find any substantial differences in population size or the population shares of neither 0 to 6 year olds, nor females of fecund age, 19-35 or 36-55 years old.

There are, however, a couple of notable differences between treatment and comparison municipalities. Most importantly, the ratio of child care coverage to employment rate of mothers of 3-6 year olds prior to the reform, is substantially lower in treatment municipalities than in comparison municipalities. In treatment municipalities, there is on average more than four employed mothers for each child care place, while the same ratio is less than three-to-one in comparison municipalities. This conforms well to intuition, since federal subsidy rates were higher for municipalities with low child care coverage prior to the reform, but also because the local political pressure for expansion of formal care is likely to be stronger in areas where child 
care was severely rationed. We also see that two of the variables indicating rurality indicate a small positive relationship with the child care expansion (average distance to zone center and ear marks per capita). This might be due to the discreteness of child care expansion; Establishing a typical child care institution increases the child care coverage rate more in smaller than in larger municipalities. In Norway, there was a very slow process of urbanization until the mid 1980s (Berg, 2005), which implies that rurality status is likely to be more or less constant during the period we consider, and should, therefore, be picked up by the municipality-specific fixed effects. ${ }^{11}$

\section{Main results}

Table IV shows our main results based on equation (1), both per child in the treatment area denoted by ITT (column 3), and per child care place denoted by TT (column 2). We focus on the estimated effects per child care place, since these reflect the size of the child care expansion. To address concerns for selection bias, we estimate equation (1) with and without the set of controls capturing important child and parental characteristics, as well as municipalityspecific fixed effects; Estimates are quite similar across the different specifications and qualitatively the same. We use as our baseline specifications the estimations including controls and municipality-specific fixed effects. Nearly all these estimates are significant at the one percent level. The reform effects for the phase-in cohorts are relatively small and mostly insignificant.

Education. In light of the recent focus on dynamic complementarities in learning, a compelling question is how universal child care affects children's educational attainment. Starting with these estimations, panel A of Table IV shows immediately the profound consequences of universal child care. Our estimated TT effect shows an additional .35 years of education per child care place, corresponding to an ITT effect of .06 years per child in the treatment area. This implies that by facilitating the supply of an additional 17,500 child care places, local governments were able to produce about 6,200 years of education. The effect per child care place is

\footnotetext{
${ }^{11}$ We have also regressed the change in the municipality's child care coverage between 1976 and 1979 on the characteristics of the municipalities listed in Table A2. Consistent with the descriptive statistics, there is little evidence of systematic relationships between the child care expansion and most of these characteristics. Again, the most notable exception is the ratio of child care to maternal employment rate prior to the reform.
} 
comparable to the gap in average education level between the Netherlands and Greece, or to the difference between the US and Ireland (OECD, 2006).

A vast literature suggests that the return to education is non-linear, with relatively high returns to high school and college completion. ${ }^{12}$ We estimate that universal child care decreases the probability of dropping out of high school by nearly 6 percentage points, while increasing the probability of attending college by almost 7 percentage points. The effect on the high school dropout-rate is almost the same as the entire gap between blacks and whites in the US. Similarly, the effect on college attendance is about two thirds of the US black-white race gap (US Census, 2007). For a final comparison, in the treatment area, the gender gaps in high school drop-out and college attendance rates in the pre-reform cohorts are about 1 and 10 percentage points, respectively.

\section{[TABLE IV ABOUT HERE]}

Earnings and welfare dependency. Two other important dimensions for evaluating the impact of public policy on long-run prospects of children are earnings and welfare dependency. In panel B of Table IV, we report the estimated effects of the child care expansion on the probability of being a low, average, high and top earner, as well as the probability of being welfare dependent. We find that the reform reduced the chances of having little or no earnings: Per child care place, the expansion in universal child care is estimated to decrease the probability of being a low earner by about 3.6 percentage points. In comparison, the probability of having at least average earnings increased by 5.1 percentage points. ${ }^{13}$ Meanwhile, the effect on high and top earners go in the opposite direction, decreasing the probability by 3.4 and 2.2 percentage points respectively. It should be noted, however, that the estimation results for high and top earners are not robust to one of the many specification tests presented below. With this caveat in mind, the counteracting effects on the top and the bottom of the earnings distribution suggest that universal child care has an equalizing effect. This finding conforms to the literature on child development suggests systematic heterogeneity in the sign and magnitude of the effects of out-of-home child care: children from disadvantaged families are expected to benefit the

\footnotetext{
${ }^{12}$ See for example Trostel (2005) for cross-country evidence on non-linearity in the return to education.

${ }^{13}$ We have also estimated the effect on the probability of having very low or no earnings (under one basic amount) to be a decrease of about 6 percentage points (significant at the one percent level).
} 
most from a universal child care system, whereas it could be less important or even detrimental for children from families with monetary and human capital to facilitate alternative arenas for child development of high quality (see e.g. Gaviria, 2002).

For welfare dependency, we find results mirroring those for low and average earnings. Specifically, the expansion in child care caused a reduction in the probability of being on welfare by almost 5 percentage points, which is a very large effect when compared to the pre-reform mean of about 16 percent.

Family formation. Panel C of Table IV displays estimates of the effects of the child care expansion on family formation. We find that the children exposed to the reform are about 8 percentage points less likely to have a child, and almost 3.5 percentage points more likely to be single with no child. There is no effect on the probability of being a single parent. These findings align well with our results on education and earnings: When young adults undertake more education, child bearing and cohabitation are delayed (Heck et al., 1997; Buckles, 2008). Whether these effects persist is an open question, but delayed child birth is often associated with a decrease in the probability of a third or fourth child, since fecundity weakens when the female ages beyond 30 (Van Noord-Zaadstra et al., 1991). In end effect, the child care expansion could therefore turn out to lower the fertility rates and reduce the family size of the exposed children.

\section{Specification checks}

This section reports results from a battery of specification tests. When considering the effect of child care on children's educational attainment, the estimates are fairly similar across the different specifications and qualitatively the same. This also holds true for most of the other outcomes, including low earner, average earner, on welfare, parent, and single no child. In comparison, the results for high earner and top earner are sensitive to one of the ten specification tests, and should therefore be interpreted with more caution. Table VI shows the bulk of estimates from our specification checks, while placebo estimates are reported in Table V, and Table VII provides results from estimations including family-specific fixed effects.

Time trend. Our DD approach identifies the child care effects from the assumption of a common 
time trend in the treatment and comparison group in the absence of the reform. A concern is that our positive effects may reflect differential time trends between the treatment and comparison municipalities, rather than a true policy impact. In Figure I, we showed graphically that the pre-reform trends in years of education were quite similar for the treatment and comparison group, but that there was a striking change in their relative outcomes after the reform. Figures A2-A4 presented in Appendix B draw similar pictures for all outcomes.

Consistent with this evidence, we find no effect of placebo reforms on the outcomes of children from the pre-reform cohorts who reside in the treatment area. Table V reports results from the placebo test, when adding interaction terms between treatment status and cohort dummies for children born in 1968 and 1969 (with the 1967-cohort as the omitted category) to equation (1). The placebo test turns on the estimated treatment effects for cohorts born in 1968 and 1969, relative to 1967. If there were differential secular time trends in the treatment and comparison municipalities, then these effects should be significantly different from zero. The results show that none of the treatment effects for cohorts born in 1968 and 1969, is significant at even the 10 percent level. Further, if differential time trends were to exaggerate the child care estimates, then the signs of the placebo effects should coincide with the signs of of our main results. On the contrary, Table $\mathrm{V}$ shows that about half of the placebo point estimates have the opposite sign of our main results, indicating, if anything, downward bias in the child care effects on these outcomes. ${ }^{14}$

\section{[TABLE V ABOUT HERE]}

To make sure that our results are not driven by secular changes between urban and rural areas coinciding with the child care reform, we further drop the three big cities (Oslo, Bergen, and Trondheim) from our analysis. Column (3) in Table VI reports estimation results excluding these cities, whereas Column (1) repeats our baseline results for comparison. The fact that our estimates vary little between the specifications increases our confidence in the empirical strategy. ${ }^{15}$

\footnotetext{
${ }^{14}$ We have also estimated equation (1) replacing the indicators for pre-reform, phase-in, and post-reform cohorts with cohort-specific dummies. Also in this case, the placebo reform effects are insignificant. Moreover, the estimated effects per child care place are fairly similar across different post-reform cohorts.

${ }^{15}$ We have also dropped the six largest cities from our analysis, yielding very similar results.
} 
As shown by Crump et al. (2009), the propensity score can be used for systematic sample selection as a precursor to regression estimation, to increase comparability between treatment and comparison groups. Motivated by this approach, we regress the change in child care coverage from 1976 to 1979 for the municipalities on the rich set of municipality characteristics listed in Table A2 in Appendix A, and discussed in Section V. After sorting the municipalities according to the predicted change in child care coverage, we divide the sample at the 10th and 90th percentiles. Finally, we estimate our baseline specification on the support sample of children living in municipalities with predicted child care growth between these threshold. The idea is that the assumption of a common time trend may be more plausible if there is stronger overlap in the covariate distribution between the treatment and control municipalities. Column (8) in Table VI reports estimates from this support sample, which conform well to the results from the baseline specification. Given the smaller sample size, it is not surprising to find that the estimates from the support sample are less precise, though generally significant at conventional levels and not significantly different from the baseline specification. ${ }^{16}$

Besley and Burgess (2004) show that allowing for differential time trends between areas in a DD regression may kill otherwise significant and large treatment effects. Column 5 in Table VI reports estimation results where we have added municipality-specific time trends to our baseline specification. The idea is to use the pre-reform data to extrapolate the time trend of each municipality into the post-reform period. This allows treatment and comparison municipalities to follow different secular trends in a limited but potentially revealing way. As expected, the estimates are less precise, as we now exploit the deviations from preexisting municipalityspecific trends to pin down the child care effects. However, it's heartening to find that the results including municipal-specific trends in general support the picture from our baseline specification; The estimated effects are higher for some outcomes, like years of education, and lower for others, such as high-school dropout. The exceptions are the results for high earner and top earner, where the estimates are substantially affected by the inclusion of municipalityspecific time trends.

\footnotetext{
${ }^{16}$ As an alternative, we have estimated the probability that a municipality is a treatment municipality. Estimating the baseline specification on the sample of children from municipalities with a predicted probability of treatment of at least 10 percent but not more than 90 percent, yields very similar results.
} 
Clustering. To account for the fact that the variation in the data we use to estimate the child care effects is at the municipality-period level, Column (2) in Table VI reports results from our baseline specification, clustering the standard errors at the municipality-period level. By doing so, we allow for shocks common to children who are born in the same period and live in the same municipality. We find that accounting for dependence within municipality-period groups does not increase our standard errors much, and the significance levels of the results are very similar. ${ }^{17}$

Selective migration. Although location decisions based on unobservable characteristics may affect our estimates, the direction of the bias is not obvious. ${ }^{18}$ On the one hand, educationoriented or labor market attached parents may be more likely to move to municipalities with high child care coverage rate. On the other hand, parents with children who need special attention or supervision may be more inclined to move to municipalities with good access to child care. Though recent empirical work finds little support for Tiebout sorting across states or municipalities according to public good provision like school quality, ${ }^{19}$ we take several steps to avoid that selective migration of families into treatment and comparison municipalities confounds our results.

To address the concern for in-migration induced by the reform, we excluded in our main analysis children from families that move between treatment and comparison municipalities during the expansion period. In addition, we control for relocation between municipalities within the treatment/comparison area; We have also performed all estimations excluding families that relocate, and the results are unchanged. However, one could argue that even the sample of stayers is selective, as out-migration could be endogenous to the child care expansion. To address this issue, we follow Hægeland et al. (2008) in using children's municipality of birth to determine whether they belong to treatment or comparison municipalities. Column (4) in Table

\footnotetext{
${ }^{17}$ Bertrand et al. (2004) show that the standard errors in DD regressions may be misstated if there is serial correlation in the municipality-period shocks. As their analysis demonstrates, we reduce the problem of serial correlation considerably by collapsing the time-series dimension into three periods: pre-reform, phase-in, and post-reform.

${ }^{18}$ Note that families living on the municipal borders could not take advantage of the child care expansion in neighboring municipalities without relocating, since eligibility was based on municipality of residency.

${ }^{19}$ See e.g. Rhode and Strumpf (2003) who find little support for Tiebout sorting across municipalities and counties using about 150 years of data.
} 
VI shows that the effects of the child care expansion is robust to using municipality of birth to determine treatment status. This finding conforms well with the results from Hægeland et al. (2008), which suggest that school quality matters little, if anything, for location decisions in Norway.

Alternative treatment definitions. In our baseline specification, we define the treatment and comparison areas by ordering municipalities according to the increase in child care coverage rate in the period 1976-1979, and then separating them at the median. Below, we make sure that our results are not artifacts of this choice of treatment definition.

In Column (6), we use the same expansion period, 1976-1979, but divide the sample at the 33rd and 67th percentiles of child care growth. Municipalities below the lower threshold are in the comparison group, while those above the upper threshold are in the treatment group. Children from municipalities in between the thresholds are excluded from the sample used for estimation. In column (7), we define the treatment and comparison according to the median child care growth, but alter the expansion period to 1977-1979. To be consistent with this new definition of the expansion period, the 1970 cohort is now defined as a pre-reform instead of a phase-in cohort. Our findings show that the child care effects are similar across treatment definitions: The estimated effects are generally statistically significant at conventional levels and not significantly different from our baseline specification. ${ }^{20}$

To get round the issue of how to draw the line between treatment and comparison municipalities we estimate equation (2), where child outcome is regressed on child care coverage in each municipality, controlling for cohort and municipality-specific fixed effects as well as a set of controls. Column (9) reports estimates from this regression. In line with the results from the baseline specification, the findings suggest that child care had positive effects on educational attainment, labor market attachment, and welfare dependency. Although not significantly different, the point estimates for educational attainment are considerably lower with the specification that is linear in child care coverage, relative to our baseline specification. For instance, whereas the baseline specification estimates the reform effects per child care place

\footnotetext{
${ }^{20}$ We have also considered expansion periods $1976-1978$, 1977-1980, and 1978-1980. For all expansion periods, we have used both thresholds: the median and 33rd vs. 67th percentile. The results confirm the picture presented above.
} 
to be .35 years of education, the linear specification suggests that creating another child care slot increases years of education of a child by .15 . It should be noted, however, that adding a quadratic term in child care coverage to equation (2) gives results for educational attainment that are very similar to our baseline specification. Specifically, our quadratic specification predicts that the rise in child care coverage from 1976 to 1979 of 17.85 percentage points led to increases per child care place of .39 for years of education and 6.5 percentage points for college attendance, whereas high-school drop-out rates reduce by 6 percentage points (all significant at a one percent level).

\section{[TABLE VI ABOUT HERE]}

Family-specific fixed effects. In this final specification test, we take advantage of the fact that we can link all children to their parents through unique individual identifiers. This allows us to identify siblings, and add family-specific fixed effects controlling for unobserved timeinvariant family characteristics. The reform effects are then identified only from comparisons of the outcomes of siblings from the pre-reform and the post-reform cohorts, who have the same family background but experience different exposure to child care. A notable feature is that these children have a sibling that is at least three years apart. This implies that children born late among the post-reform cohorts, when the child care coverage rate was highest, will be undersampled. ${ }^{21}$ Consequently, to compare the family-fixed effect results with our main results would be inappropriate. Instead, we restrict our sample to children from families with siblings from at least two of the three groups of cohorts; pre-reform, phase-in, and postreform. ${ }^{22}$ Next, we estimate equation (1) on this subsample, with and without family-specific fixed effects. The results are reported in Table VII, and show that the reform effects are, as expected, generally smaller and less precisely estimated in this subsample. More importantly, comparing the results with and without family-specific fixed effects increases our confidence in the empirical strategy, since the point estimates are quite similar, and never significantly different. It should be noted that when estimating the effects in subsamples by mother's education and child sex,

\footnotetext{
${ }^{21}$ Notice that a child born in 1976, say, must have a sibling at least 7 years his senior (born in 1969, and therefore in the pre-reform cohorts) to be included in this sample.

${ }^{22}$ To gain efficiency, we include the phase-in cohorts, but they will not contribute to identifying the child care effects.
} 
as below, we do find large child care effects. For example, when considering children with low educated mothers, the family-fixed effect specification produces estimates that are very close to the results from our main specification.

[TABLE VII ABOUT HERE]

\section{Heterogeneous effects of child care}

Our main results show strong positive effects of child care on children's long-run outcomes, raising educational attainment, strengthening labor market attachment, and lifting people out of welfare dependency. However, estimating the average effect for the treatment group as a whole may conceal important differences in the consequences of the reform across subgroups. For instance, Melhuish et al. (2004, 2008) suggest that girls and children with low educated parents benefit most from child care attendance. To address this question, we estimate our model for different subsamples.

In Table VIII, we report results from subsamples divided by the child's sex (columns 2 and 3) and by the mother's education (columns 4 and 5). Column 1 repeats our baseline estimates for ease of comparison. Considering first the estimated effects by the child's sex, we find that most, if not all, of the reduction in the probability of being low and average earners relates to girls. This indicates that universal child care may contribute to closing the gender wage gap. Interestingly, the subsample results also reveal that it is mostly girls who delay child bearing and family formation as adults when exposed to child care. When it comes to mother's education, we find that most of the benefits associated with universal child care relate to children of low educated mothers. The child care reform could therefore be expected to increase intergenerational mobility. ${ }^{23}$

\section{[TABLE VIII ABOUT HERE]}

\footnotetext{
${ }^{23}$ We have also estimated the model separately by number of siblings, parents' age, mother's labor market attachment, and father's education. We generally find small differences across the subsamples, although the estimates are often more imprecise.
} 
Like in Baker et al. (2008), it can be difficult to interpret the differences in our estimates across subpopulations because there could both be differences in child care take-up and potentially heterogenous impacts of uptake. Unfortunately, we do not have data on child care use by child and parental characteristics. The results in this section therefore assume the same take-up rate across the subpopulations. This is admittedly a strong assumption, and we should have this caveat in mind when interpreting the above subsample results. However, when it comes to child's sex the assumption may be less controversial as child care institutions sought to balance the composition of children. When considering mother's education, it is perhaps most likely that we underestimate the reform effects on children with low educated mothers, since high educated married mothers are more attached to the labor market and should therefore be more likely to use child care.

\section{Mechanisms}

In this section, we take a closer look at the mechanisms behind our results. We first focus on how the counterfactual mode of child care might influence our results. Next, we turn our attention to other possible mechanisms, before discussing the financial costs and benefits associated with the child care expansion.

Maternal employment. When interpreting our estimated effects of universal child care, a crucial point is the counterfactual mode of care, i.e. the type of care the children would be exposed to in the absence of the reform. There are two distinct counterfactual modes of care to formal child care. The first is parental care, while the second is informal care, including relatives, unlicensed care givers, and other irregular care givers such as friends and neighbors. A shift from parental care to formal child care could affect children differently than a shift from informal care, which is likely to be of inferior quality (see e.g. Datta Gupta and Simonsen, 2007).

If we knew the effect of the child care expansion on maternal employment, we could hone in on the counterfactual mode of care. Following Blau and Currie (2006), consider the following three combination of mother's work and child care decision: not working and maternal care, working and informal care, and working and formal care. If the new subsidized formal 
child care led to a shift from parental to formal care, we would expect it to affect maternal employment rates also. ${ }^{24}$.

Havnes and Mogstad (2009) estimate the effect of the child care reform on full-time and part-time work of married mothers. To this end, they use a DD approach, comparing the growth rate in employment of mothers with the youngest child aged 3 to 6 years living in municipalities where child care coverage expanded a lot (i.e. the treatment group), with the growth rate for mothers with the youngest child of the same age who live in municipalities with little or no increase in child care (i.e. the comparison group). The analysis provides strong and robust evidence that the new subsidized child care crowds out informal care arrangements, with almost no net increase in total care use or maternal labor supply. ${ }^{25}$

As our sample differs somewhat from theirs, we re-examine the reform effect on maternal employment. ${ }^{26}$ The precise DD results presented in Table IX conform to Havnes and Mogstad (2009). The effect of the .1785 increase child care coverage rate is estimated to have caused less than one percentage point increase in maternal employment. This implies a .04 percentage point increase in maternal employment per percentage point increase in the child care coverage rate, which in turn suggests that the new child care slots were associated with a 96 percent crowding out of informal care. Consequently, our positive results of child care on children's outcomes should be interpreted as reflecting a shift mostly from informal rather than parental care.

\section{[TABLE IX ABOUT HERE]}

\footnotetext{
${ }^{24}$ It is possible that non-working mothers were taking up some of the new care child care slots. However, survey results reported in Leira (1992) suggests that the number of non-working mothers using formal child care did not increase over the period 1973-1985

${ }^{25} \mathrm{~A}$ battery of specification checks support their results, including a placebo reform, the inclusion and exclusion of a rich set of controls, a triple-difference approach using mothers of 7-10 year olds as a second comparison group, and the inclusion of individual-specific and municipality-specific fixed effects. Moreover, their subsample analysis, estimating the model separately by education and age, shows no effect on maternal labor supply for these subgroups.

${ }^{26}$ We estimate the following regression model by OLS, with controls listed in Table III and municipality-specific fixed effects:

$Y_{j t}=\gamma_{0}+\gamma_{1}$ Treat $_{j}+\gamma_{2}\left(\right.$ Treat $_{j} \times$ Phasein $\left._{t}\right)+\theta\left(\right.$ Treat $_{j} \times$ Post $\left._{t}\right)+\psi_{1}$ Phasein $_{t}+\psi_{2}$ Post $_{t}+X_{j t}^{\prime} \beta+\epsilon_{j t}$,

where $Y_{j t}$ is equal to 1 if mother $j$ works when her child is between 3 and 6 years old (and 0 otherwise). The

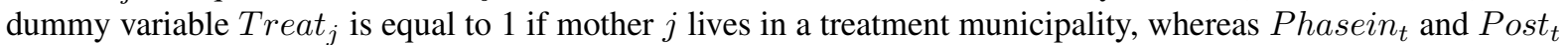
are dummy variables equal to 1 when the observation is from phase-in cohorts and post-reform cohorts, respectively. If a mother has more than one child from either the pre-reform, the phase-in or the post-reform cohorts, we consider the youngest child only.
} 
The shift from informal to formal care seems relevant for policy debates about universally accessible child care also in other countries. Cascio (2009) and Lundin, Mörk and Öckert (2008) find no effect on maternal labor supply for married mothers in the US and Sweden, respectively, from increased access to subsidized child care. Also, while Gelbach (2002), Berlinski and Galiani (2007) and Baker et al. (2008) find that subsidized child care has a positive effect on maternal labor supply, they all find considerable crowding out of informal care arrangements.

Other possible mechanisms. A concern for the interpretation of the estimated reform effect is that the child care expansion could be associated with changes in the quality of formal care. If the quality of child care institutions improved in the treatment municipalities relative to the comparison municipalities, we could potentially overstate the impact of the new child care places. However, there is no evidence of such quality changes over this period. Considering Table $X$, it seems that, if anything, the quality of formal child care may have deteriorated somewhat in the treatment group compared to the comparison group: From 1975 to 1979, the number of children per teacher increased somewhat in the treatment group from just under 17 to about 19 children, while the opposite was true in the comparison group, with a decrease from about 19 to just over 17 children per teacher. The same holds true for the number of children per employee, where the difference between the groups shifted about two points in favor of the comparison group from 1975 to 1979. Unfortunately, we do not have data on other aspects of child care quality. In any case, Blau (1999b) shows that child care characteristics, such as group size, staff-child ratio, and employee training, have little association with child development.

\section{[TABLE X ABOUT HERE]}

The fact that the reform had little impact on maternal employment also means that it is unlikely that increased family income is the driving factor behind the positive effects. The child care subsidies could be interpreted as a modest increase in family income, depending on the costs associated with alternative modes of care. However, Gulbrandsen et al. (1982) report small differences in the price of formal child care and unlicensed care givers in Norway. In any case, Løken (2009) finds little, if any, causal effect of family income on children's outcomes in Norway in the 1970s, mirroring evidence from the US (Blau, 1999a). 
Another possible mechanism behind our results is that the access to child care made it easier for mothers to undertake education, which may spill over to child outcomes. We examine this mechanism by estimating the baseline specification of equation (1), with mother's years of education when the child is 16 years old as the dependent variable. As shown in Table IX, the reform had no impact on mother's education. In any case, Black et al. (2005b) find little evidence of a causal relationship between parents' education and children's education in Norway. Consequently, we can rule out intergenerational transmission of education as an important mechanism behind the positive effects of the child care reform.

Finally, we consider the impact of the child care expansion on family size. The well-known quantity-quality model of fertility introduced by Becker and Lewis (1973) suggests that greater family size negatively affects parents' investments in child development through resource dilution. If increased access to child care promotes larger families, then the reform may reduce children's human capital, offsetting the positive effects of actual child care attendance. To investigate this, we estimate the baseline specification of equation (1), replacing child outcome with completed family size (measured in 2006) as the dependent variable. Table IX shows that the child care expansion caused a modest .1 increase in family size per child care place. Moreover, Black et al. (2005a), using data from Norway, suggest no causal effect of family size on children's adult outcomes, despite a strong correlation. This implies that changes in family size are of little concern for the interpretation of our results.

\section{IX.1 Costs and benefits}

Though a full-fledged cost-benefit-analysis is beyond the scope of this paper, some back-ofthe-envelope calculations suggests that the child care expansion produced high pecuniary returns to the children, and that it was cost-effective relative to other types of public investments in child development.

Costs. In the Kindergarten White Paper (NOU, 1972), the government estimated the annual budgetary cost per child care place to about USD 5,400. This gives a total cost of just over USD 21,000 for the four years considered. In addition, investment costs are estimated to be about USD 12,000 per child care place, adding about USD 1,200 to the annual cost if written 
down over ten years. Compared to other types of public investments in child development, child care seems to be a comparatively inexpensive alternative. Using exogenous variation in tax revenues, Hægeland et al. (2008) estimate that an increase in annual spending of USD 1500 per pupil in primary school would raise test scores by only about 0.2 standard deviations. Meanwhile, the annual municipal expenditure per pupil in primary and lower secondary school was about USD 11,000 in 2006 (Statistics Norway: Municipal accounting statistics, 2007).

Benefits. It is difficult to assess the pecuniary returns over the children's lifetime to the child care reform, but as an indication we use our baseline estimate to derive the expected returns to education. In Norway, the average return on earnings per completed year of education is about five percent, while payoffs to high school completion and college attendance are about nine and 23 percent respectively (Hægeland et al., 1999). We further use average annual wages from 2006 of USD 56,000 and assume a working life of 40 years and a real interest rate of two percent. Our baseline estimate of .35 years of education per child care place then implies an increase in annual earnings of just under USD 1,000 per year or an increase in life time earnings of about USD 27,000. In comparison, college attendance implies an increase in earnings of over USD 13,000 annually, or almost USD 370,000 in lifetime earnings for these children. Since child care is estimated to lift about seven percent of the population into college attendance, this gives a payoff of about USD 25,000 per additional child care place. Similarly, the effect on

high school completion indicates an effect of about USD 5,000 annually, or USD 145,000 in lifetime earnings, implying an effect of just over USD 8,000 per child care place. If completing high school or attending college affects the probability of additional schooling, then the effects are even stronger.

\section{Conclusion}

There is a heated debate in the US and Canada, as well as in many European countries, about a move towards subsidized, universally accessible child care or preschool. This controversy has been fuelled by a number of studies showing that early educational programs can generate learning gains in the short-run and, in many cases, improve the long-run prospects of children 
from poor families (see e.g. Karoly et al., 2005). While the results from these studies are encouraging, the programs evaluated were unusually intensive and involve small numbers of particularly disadvantaged children from a few cities in the US. A major concern is therefore that this evidence may tell us little about the effects of universal child care systems, offered to the entire population (Baker et al., 2008). This paper contributes by providing first evidence of the impact of universal child care on children's long-run outcomes.

Specifically, we analyze the introduction of subsidized, universally accessible child care in Norway, examining the impact on the adult outcomes of children with married mothers. Our precise and robust difference-in-difference estimates show that child care exposure improves the long-run prospects of children considerably. This is true with regard to both educational attainment and labor market attachment, as well as welfare dependency. In aggregate terms, the additional 17,500 child care places produced 6,200 years of education. The child care expansion also raised the chances of completing high school and attending college, in orders of magnitude similar to the black-white race gaps in the US. Consistent with the evidence of higher education and stronger labor market attachment, we also find that children exposed to child care delayed child bearing and family formation as adults. Our subsample analysis indicates that most the effect on education stems from children with low educated mothers, whereas most of the effect on earnings relates to girls. This suggests that good access to subsidized child care levels the playing field by increasing intergenerational mobility and closing the gender wage gap.

Whether these positive findings for Norway would extend to other countries is an open question. However, the Scandinavian countries were the first to introduce universally accessible child care, and their experience is currently a unique - and perhaps the only - source of information about its long-run consequences.

UNIVERSITY OF OSLO

STATISTICS NORWAY 


\section{References}

Angrist, J. D. (2001): "Estimations of Limited Dependent Variable Models with Dummy Endogenous Regressors: Simple Strategies for Empirical Practice," Journal of Business \& Economic Statistics, 19(1), 2-16.

Angrist, J. D., AND K. LANG (2004): "Does School Integration Generate Peer Effects? Evidence from Boston's Metco Program," American Economic Review, 94(5), 1613-1634.

AtKinson, A. B., L. RAINWATER, AND T. M. SMEEDing (1995): Income distribution in OECD countries : evidence from the Luxembourg Income Study. OECD Publications and Information Center, Paris.

Baker, M., J. Gruber, And K. Milligan (2008): “Universal Child Care, Maternal Labor Supply, and Family Well-Being," Journal of Political Economy, 116(4), 709-745.

BARnetT, W. S. (1995): “Long-Term Effects of Early Childhood Programs on Cognitive and School Outcomes," The Future of Children, 5(3), 25-50.

Becker, G. S. (1964): Human Capital: A Theoretical and Empirical Analysis, With Special Reference to Education. Univ of Chicago Press, Boston, MA.

BeCKer, G. S., AND H. G. LEwIS (1973): “On the Interaction between the Quantity and Quality of Children,” Journal of Political Economy, 81(2), 279-288.

BERG, P. (2005): “Ulik respons på fraflytting og sentralisering," Statistiske Analyser 69, Statistics Norway.

BERLINSKI, S., AND S. GALIANI (2007): “The effect of a large expansion of pre-primary school facilities on preschool attendance and maternal employment," Labour Economics, 14(3), 665-680.

Berlinski, S., S. Galiani, And P. Gertler (2009): “The effect of pre-primary education on primary school performance," Journal of Public Economics, 93(1-2), 219-234. 
Berlinski, S., S. GAliani, And M. Manacorda (2008): "Giving children a better start: Preschool attendance and school-age profiles," Journal of Public Economics, 92(5-6), 14161440.

Bertrand, M., E. Duflo, and S. Mullainathan (2004): "How Much Should We Trust Differences-in-Differences Estimates?," The Quarterly Journal of Economics, 119(1), 249275.

Besley, T., And R. Burgess (2004): "Can Labor Regulation Hinder Economic Performance? Evidence from India,” The Quarterly Journal of Economics, 119(1), 91-134.

Besley, T., AND A. CASE (2000): "Unnatural Experiments? Estimating the Incidence of Endogenous Policies,” Economic Journal, 110(467), F672-F694.

Black, S. E., P. J. Devereux, and K. G. Salvanes (2005a): "The More the Merrier? The Effect of Family Size and Birth Order on Children's Education,' The Quarterly Journal of Economics, 120(2), 669-700.

(2005b): “Why the Apple Doesn't Fall Far: Understanding Intergenerational Transmission of Human Capital," American Economic Review, 95(1), 437-449.

Blau, D. M. (1999a): "The Effect of Child Care Characteristics on Child Development," Journal of Human Resources, 34(4), 786-822.

(1999b): “The Effect Of Income On Child Development," The Review of Economics and Statistics, 81(2), 261-276.

BuCKLES, K. (2008): "Understanding the Returns to Delayed Childbearing for Working Women," American Economic Review, 98(2), 403-407.

CARneiro, P., And J. J. HeckMAN (2004): "Inequality in America: What Role for Human Capital Policies?," in Human Capital Policy, ed. by J. J. Heckman, and A. B. Krueger. The MIT Press.

CASCIO, E. (2009): "Maternal Labor Supply and the Introduction of Kindergartens into American Public Schools," Journal of Human Resources, 44, 140-170. 
Crump, R. K., V. J. Hotz, G. W. Imbens, And O. A. Mitnik (2009): "Dealing with limited overlap in estimation of average treatment effects," Biometrika, 96(1), 187-199.

Cullen, J. B., B. A. Jacob, And S. LevitT (2006): “The Effect of School Choice on Participants: Evidence from Randomized Lotteries," Econometrica, 74(5), 1191-1230.

Cunha, F., And J. J. HeCKMAn (2008): "Formulating, Identifying and Estimating the Technology of Cognitive and Noncognitive Skill Formation," Journal of Human Resources, 43(4), $738-782$.

Currie, J. (2001): "Early Childhood Education Programs," Journal of Economic Perspectives, 15(2), 213-238.

EU (2002): "Presidency Conclusions," Barcelona European Council 15 and 16 March 2002, Barcelona.

FitZPATRICK, M. D. (2008): "Starting School at Four: The Effect of Universal PreKindergarten on Children's Academic Achievement," B.E. Journal of Economic Analysis and Policy, 8(1), 1-38.

GAVIRIA, A. (2002): "Intergenerational mobility, sibling inequality and borrowing constraints," Economics of Education Review, 21(4), 331-340.

Gelbach, J. B. (2002): "Public Schooling for Young Children and Maternal Labor Supply," American Economic Review, 92(1), 307-322.

Gormley, William T., J., And T. Gayer (2005): "Promoting School Readiness in Oklahoma: An Evaluation of Tulsa's Pre-K Program," Journal of Human Resources, 40(3), $533-558$.

Gulbrandsen, L., J. A. LEA, And S. STOKKE (1982): "Barnetilsyn hos småbarnsfamilier," INAS notat 82:13, Institutt for anvendt sosialvitenskapelig forskning, Oslo.

Gupta, N. D., And M. Simonsen (2007): "Non-cognitive Child Outcomes and Universal High Quality Child Care,” IZA Discussion Papers 3188, Institute for the Study of Labor (IZA). 
HAIDER, S., ANd G. Solon (2006): "Life-Cycle Variation in the Association between Current and Lifetime Earnings," American Economic Review, 96(4), 1308-1320.

Hanushek, E. A., J. F. Kain, J. M. Markman, and S. G. Rivkin (2003): "Does peer ability affect student achievement?," Journal of Applied Econometrics, 18(5), 527-544.

HAVnes, T., AND M. MogSTAD (2009): “The irrelevance of subsidized child care for maternal employment," Unpublished.

Heck, K. E., K. C. Schoendorf, S. J. Ventura1, and J. L. Kiely (1997): “Delayed Childbearing by Education Level in the United States, 1969-1994," Maternal and Child Health Journal, 1(2), 81-88.

HeCKMAN, J. J. (2006): “Skill Formation and the Economics of Investing in Disadvantaged Children," Science, 312(5782), 1900-1902.

Heckman, J. J., J. STIXRUD, AND S. URZUA (2006): “The Effects of Cognitive and Noncognitive Abilities on Labor Market Outcomes and Social Behavior," Journal of Labor Economics, 24(3), 411-482.

Herbst, C. M., And E. TeKin (2008): “Child Care Subsidies and Child Development," IZA Discussion Papers 3836, Institute for the Study of Labor (IZA).

HÆgeland, T., T. J. Klette, and K. G. Salvanes (1999): “Declining Returns to Education in Norway? Comparing Estimates across Cohorts, Sectors and Over Time," Scandinavian Journal of Economics, 101(4), 555-576.

HÆgeland, T., O. RaAum, and K. G. Salvanes (2008): "Pennies from Heaven? Using Exogeneous Tax Variation to Identify Effects of School Resources on Pupil Achievements," IZA Discussion Papers 3561, Institute for the Study of Labor (IZA).

IMBEnS, G., AND J. WoOLDRIDGE (2009): "Recent Developments in the Econometrics of Program Evaluation,” Journal of Economic Literature, 47(1), 5-86.

KAROLY, L. A., M. R. KilbuRn, AND J. S. CANNON (2005): Early Childhood Interventions: Proven Results, Future Promise. RAND Corporation, Santa Monica, CA. 
Knudsen, E. I., J. J. Heckman, J. L. CAmeron, And J. P. Shonkoff (2006): “Economic, neurobiological, and behavioral perspectives on building America's future workforce," Proceedings of the National Academy of Sciences, 103(27), 10155-10162.

LeIRA, A. (1992): Welfare States and Working Mothers. Cambridge University Press.

LemieuX, T. (2006): “Postsecondary Education and Increasing Wage Inequality," American Economic Review, 96(2), 195-199.

LøKEN, K. V. (2009): “Family income and children's education: Using the Norwegian oil boom as a natural experiment," Labour Economics, In Press.

Loeb, S., M. Bridges, D. Bassok, B. Fuller, And R. W. Rumberger (2007): "How much is too much? The influence of preschool centers on children's social and cognitive development," Economics of Education Review, 26(1), 52 - 66, The Economics of Early Childhood Education.

Lundin, D., E. MÖRK, AND B. ÖCKERT (2008): "How far can reduced childcare prices push female labour supply?," Labour Economics, 15(4), 647-659.

Magnuson, K. A., C. Ruhm, And J. Waldfogel (2007): "Does prekindergarten improve school preparation and performance?," Economics of Education Review, 26(1), 33-51.

Melhuish, E., K. Sylva, P. Sammons, I. Siraj-Blatchford, B. Taggart, M. B. Phan, And A. MALin (2008): “The Early Years: Preschool Influences on Mathematics Achievement," Science, 321(5893), 1161-1162.

Melhuish, E., K. Sylvia, P. Sammons, I. Siraj-Blatchford, and B. Taggart (2004): “The Effective Provision of Pre-School and Primary Education (EPPE) Project: Findings from Pre-school to end of Key Stage 1," SSU Report 01, University of London, Institute of Education.

NOU (1972:39): “Preschools,” White paper, Ministry of children's and family affairs.

OECD (2004): "Female Labour Force Participation: Past Trends and Main Determinants in OECD Countries,” Mcm background paper, OECD Economics Department, Barcelona. 
(2006): Education at a glance. OECD Indicators.

Rhode, P. W., And K. S. Strumpf (2003): “Assessing the Importance of Tiebout Sorting: Local Heterogeneity from 1850 to 1990," American Economic Review, 93(5), 1648-1677.

ShONKOFF, J. P., AND D. A. Phillips (2000): From Neurons to Neighborhoods: The Science of Early Childhood Development. National Academy Press.

Telhaug, A. O., O. A. Mediås, and P. Aasen (2006): “The Nordic Model in Education: Education as part of the political system in the last 50 years," Scandinavian Journal of Educational Research, 50(3), 245 - 283.

Trostel, P. A. (2005): "Nonlinearity in the return to education," Journal of Applied Economics, 8(1), 191-202.

US CENSUS (2007): Educational Attainment in the United States.

van Noord-ZaAdstra, B. M., C. W. Looman, H. Alsbach, J. D. Habbema, E. R. TE Velde, And J. KarbaAt (1991): “Understanding the Returns to Delayed Childbearing for Working Women," British Medical Journal, 302(6789), 1361-1365.

VOLCKMAR, N. (2008): “Knowledge and Solidarity: The Norwegian social-democratic school project in a period of change, 1945-2000," Scandinavian Journal of Educational Research, 52(1), 1-15. 


\section{Tables}

Table I: Child care institutions by ownership structure

\begin{tabular}{lcccc}
\hline & $\mathbf{1 9 7 5}$ & $\mathbf{1 9 7 7}$ & $\mathbf{1 9 7 9}$ & $\mathbf{1 9 8 1}$ \\
\hline Private (\%) & 28.4 & 26.7 & 26.3 & 21.9 \\
Municipality (\%) & 48.6 & 45.4 & 46.9 & 51.2 \\
Church (\%) & 7.3 & 8.0 & 8.6 & 8.6 \\
Cooperatives (\%) & 5.6 & 8.2 & 9.7 & 10.0 \\
\hline No. of child care institutions & 880 & 1,469 & 2,294 & 2,754 \\
No. of children in child care (3-6 y.o.) & 25,536 & 43,239 & 63,218 & 73,152 \\
Coverage rate (3-6 y.o., \%) & 10.0 & 17.6 & 28.1 & 34.2 \\
\hline
\end{tabular}

Notes: Private ownership indicates ownership by a private firm, organisation or foundation. Cooperatives are parental or residential. Categories not reported are ownership by state, regions and other.

Table II: Descriptive statistics: Outcome variables

\begin{tabular}{lcccc}
\hline & $\begin{array}{c}\text { Level }- \\
\text { Treated } \\
\text { Pre-reform }\end{array}$ & Pre-reform & \multicolumn{3}{c}{$\begin{array}{c}\text { Treated - Comparison } \\
\text { Phase-in }\end{array}$} & Post-reform \\
\hline Years of education & $12.65[2.56]$ & 0.0435 & 0.0627 & 0.1180 \\
Attended college & $0.3740[0.4839]$ & 0.0074 & 0.0138 & 0.0231 \\
High school dropout & $0.2625[0.4400]$ & -0.0010 & -0.0031 & -0.0101 \\
Low earner & $0.1546[0.3616]$ & -0.0019 & -0.0031 & -0.0068 \\
Average earner & $0.6929[0.4613]$ & 0.0067 & 0.0076 & 0.0172 \\
High earner & $0.1620[0.3684]$ & 0.0145 & 0.0149 & 0.0104 \\
Top earner & $0.0417[0.1999]$ & 0.0066 & 0.0049 & 0.0033 \\
On welfare & $0.1624[0.3688]$ & -0.0104 & -0.0131 & -0.0193 \\
Parent & $0.8082[0.3937]$ & -0.0113 & -0.0214 & -0.0304 \\
Single, no child & $0.1396[0.3466]$ & 0.0073 & 0.0112 & 0.0160 \\
Single, parent & $0.0838[0.2770]$ & -0.0030 & -0.0010 & -0.0037 \\
\hline No. of children (level) & & $77,933-87,832$ & $74,182-83,621$ & $84,052-91,406$ \\
\hline
\end{tabular}

Notes: Pre-reform cohorts are born 1967-1969, phase-in cohorts are born 1970-1972, and post-reform cohorts are born 1973-1976. Treatment (comparison) municipalities are above (below) the median in child care coverage growth from 1976 to 1979 . Outcomes are defined in Section V. Standard deviations are in brackets. 
Table III: Descriptive statistics: Control variables

\begin{tabular}{lcccc}
\hline & $\begin{array}{c}\text { Level }- \\
\text { Treated }\end{array}$ & \multicolumn{3}{c}{ Treated - Comparison } \\
& Pre-reform & Pre-reform & Phase-in & Post-reform \\
\hline Male & 0.5069 & -0.0014 & 0.0036 & 0.0017 \\
& {$[0.5000]$} & $\{-0.0020\}$ & $\{0.0051\}$ & $\{0.0024\}$ \\
No. of older siblings & 2.1319 & -0.0818 & -0.0736 & -0.1118 \\
& {$[1.2343]$} & $\{-0.0456\}$ & $\{-0.0432\}$ & $\{-0.0718\}$ \\
Mother's age at & 23.3286 & 0.5671 & 0.5916 & 0.6472 \\
first birth & {$[4.0432]$} & $\{0.1021\}$ & $\{0.1119\}$ & $\{0.1223\}$ \\
Father's age at & 26.5592 & 0.4936 & 0.4867 & 0.5444 \\
first birth & {$[5.2946]$} & $\{0.0675\}$ & $\{0.0705\}$ & $\{0.0823\}$ \\
Mother's education when & 9.6618 & 0.2805 & 0.2817 & 0.3072 \\
child 2 y.o. & {$[2.0739]$} & $\{0.0987\}$ & $\{0.0992\}$ & $\{0.1066\}$ \\
Father's education when & 10.3715 & 0.3730 & 0.3787 & 0.4044 \\
child 2 y.o. & {$[2.8162]$} & $\{0.0971\}$ & $\{0.0995\}$ & $\{0.1065\}$ \\
Immigrant & 0.0566 & 0.0110 & 0.0165 & 0.0162 \\
& {$[0.2311]$} & $\{0.0355\}$ & $\{0.0535\}$ & $\{0.0534\}$ \\
Relocated & 0.0358 & -0.0016 & 0.0021 & 0.0070 \\
& {$[0.1858]$} & $\{-0.0061\}$ & $\{0.0061\}$ & $\{0.0172\}$ \\
\hline
\end{tabular}

No. of children (level) $77,933-87,832 \quad 74,182-83,621 \quad 84,052-91,406$

Notes: Pre-reform cohorts are born 1967-1969, phase in-cohorts are born 1970-1972, and post-reform cohorts are born 1973-1976. Treatment (comparison) municipalities are above (below) the median in child care coverage growth from 1976 to 1979. Control variables are defined in Section V. Standard deviations are in square brackets, and normalized differences are in curly brackets. 
Table IV: Main results

\begin{tabular}{|c|c|c|c|c|c|}
\hline & $\begin{array}{l}\text { (1) } \\
\text { TT }\end{array}$ & $\begin{array}{l}\text { (2) } \\
\text { ITT }\end{array}$ & $\begin{array}{c}(3) \\
\text { SE(ITT) }\end{array}$ & $\begin{array}{c}(4) \\
\text { Mean }\end{array}$ & $\begin{array}{c}\text { (5) } \\
\text { Controls }\end{array}$ \\
\hline \multicolumn{6}{|c|}{ A. Educational attainment } \\
\hline \multirow[t]{2}{*}{ Years of education } & $0.4129^{* * *}$ & $0.0737^{* * *}$ & 0.0174 & 12.76 & No \\
\hline & $0.3523^{* * *}$ & $0.0629^{* * *}$ & 0.0155 & & Yes \\
\hline \multirow[t]{2}{*}{ Attended college } & $0.0868^{* * *}$ & $0.0155^{* * *}$ & 0.0034 & 0.3922 & No \\
\hline & $0.0685^{* * *}$ & $0.0122^{* * *}$ & 0.0031 & & Yes \\
\hline \multirow[t]{2}{*}{ High school dropout } & $-0.0498^{* * *}$ & $-0.0089^{* * *}$ & 0.0029 & 0.2474 & No \\
\hline & $-0.0584^{* * *}$ & $-0.0104^{* * *}$ & 0.0028 & & Yes \\
\hline \multicolumn{6}{|c|}{ B. Earnings and welfare dependency } \\
\hline \multirow[t]{2}{*}{ Low earner } & $-0.0281^{* *}$ & $-0.0050^{* *}$ & 0.0025 & 0.1541 & No \\
\hline & $-0.0359^{* * *}$ & $-0.0064^{* * *}$ & 0.0025 & & Yes \\
\hline \multirow[t]{2}{*}{ Average earner } & $0.0596^{* * *}$ & $0.0106^{* * *}$ & 0.0032 & 0.6888 & No \\
\hline & $0.0514^{* * *}$ & $0.0092^{* * *}$ & 0.0031 & & Yes \\
\hline \multirow[t]{2}{*}{ High earner } & $-0.0219^{* *}$ & $-0.0039^{* *}$ & 0.0023 & 0.1545 & No \\
\hline & $-0.0337^{* * *}$ & $-0.0060^{* * *}$ & 0.0022 & & Yes \\
\hline \multirow[t]{2}{*}{ Top earner } & $-0.0183^{* * *}$ & $-0.0033^{* * *}$ & 0.0011 & 0.0375 & No \\
\hline & $-0.0220^{* * *}$ & $-0.0039^{* * *}$ & 0.0011 & & Yes \\
\hline \multirow[t]{2}{*}{ On welfare } & $-0.0496^{* * *}$ & $-0.0089^{* * *}$ & 0.0025 & 0.1599 & No \\
\hline & $-0.0511^{* * *}$ & $-0.0091^{* * *}$ & 0.0025 & & Yes \\
\hline \multicolumn{6}{|l|}{ C. Family formation } \\
\hline \multirow[t]{2}{*}{ Parent } & $-0.1029^{* * *}$ & $-0.0184^{* * *}$ & 0.0030 & 0.7764 & No \\
\hline & $-0.0799^{* * *}$ & $-0.0143^{* * *}$ & 0.0029 & & Yes \\
\hline \multirow[t]{2}{*}{ Single, no child } & $0.0472^{* * *}$ & $0.0084^{* * *}$ & 0.0026 & 0.1506 & No \\
\hline & $0.0347^{* * *}$ & $0.0062^{* * *}$ & 0.0025 & & Yes \\
\hline \multirow[t]{2}{*}{ Single, parent } & -0.0036 & -0.0007 & 0.0018 & 0.0764 & No \\
\hline & -0.0025 & -0.0004 & 0.0017 & & Yes \\
\hline
\end{tabular}

${ }^{*} p<0.10,{ }^{* *} p<0.05,{ }^{* * *} p<0.01$ (one-tailed)

Notes: Estimations are based on OLS on equation (1), with and without municipal-specific fixed effects and the controls listed in Table III. The outcome variables are defined in Section V. The sample consists of 499,026 children from birth cohorts 1967-1976. ITT/TT $=.1785$ (i.e. the increase in child care coverage following the reform in the treatment group relative to the comparison group). Mean refers to the pre-reform means in the treatment group. Standard errors are robust to within family clustering and heteroskedasticity. 
Table V: Robustness: Placebo reform.

\begin{tabular}{|c|c|c|c|c|c|}
\hline & $\begin{array}{c}(1) \\
\text { TT } 1968\end{array}$ & $\begin{array}{c}(2) \\
\text { TT } 1969\end{array}$ & $\begin{array}{c}(3) \\
\text { TT Phase-in }\end{array}$ & $\begin{array}{c}(4) \\
\text { TT Post }\end{array}$ & $\begin{array}{c}(5) \\
\text { Mean }\end{array}$ \\
\hline Years of education & $\begin{array}{l}-0.0009 \\
(0.1520)\end{array}$ & $\begin{array}{l}-0.0506 \\
(0.1512)\end{array}$ & $\begin{array}{c}0.0913 \\
(0.1243)\end{array}$ & $\begin{array}{c}0.3349^{* * *} \\
(0.1238)\end{array}$ & 12.76 \\
\hline Attended college & $\begin{array}{c}0.0057 \\
(0.0295)\end{array}$ & $\begin{array}{l}-0.0261 \\
(0.0294)\end{array}$ & $\begin{array}{c}0.0268 \\
(0.0243)\end{array}$ & $\begin{array}{c}0.0616^{* * *} \\
(0.0243)\end{array}$ & 0.3922 \\
\hline High school dropout & $\begin{array}{l}-0.0167 \\
(0.0284)\end{array}$ & $\begin{array}{l}-0.0031 \\
(0.0281)\end{array}$ & $\begin{array}{l}-0.0236 \\
(0.0231)\end{array}$ & $\begin{array}{c}-0.0650^{* * *} \\
(0.0228)\end{array}$ & 0.2474 \\
\hline Low earner & $\begin{array}{l}-0.0013 \\
(0.0241)\end{array}$ & $\begin{array}{l}-0.0155 \\
(0.0240)\end{array}$ & $\begin{array}{l}-0.0148 \\
(0.0198)\end{array}$ & $\begin{array}{c}-0.0416^{* *} \\
(0.0198)\end{array}$ & 0.1541 \\
\hline Average earner & $\begin{array}{l}-0.0087 \\
(0.0295)\end{array}$ & $\begin{array}{c}0.0250 \\
(0.0294)\end{array}$ & $\begin{array}{c}0.0041 \\
(0.0243)\end{array}$ & $\begin{array}{c}0.0570^{* * *} \\
(0.0243)\end{array}$ & 0.6888 \\
\hline High earner & $\begin{array}{c}0.0156 \\
(0.0233)\end{array}$ & $\begin{array}{c}0.0274 \\
(0.0231)\end{array}$ & $\begin{array}{c}0.0097 \\
(0.0190)\end{array}$ & $\begin{array}{l}-0.0192 \\
(0.0185)\end{array}$ & 0.1545 \\
\hline Top earner & $\begin{array}{l}-0.0133 \\
(0.0130)\end{array}$ & $\begin{array}{l}-0.0058 \\
(0.0127)\end{array}$ & $\begin{array}{c}-0.0177^{* *} \\
(0.0104)\end{array}$ & $\begin{array}{c}-0.0284^{* * *} \\
(0.0099)\end{array}$ & 0.0375 \\
\hline On welfare & $\begin{array}{c}0.0264 \\
(0.0246)\end{array}$ & $\begin{array}{c}0.0258 \\
(0.0244)\end{array}$ & $\begin{array}{c}0.0022 \\
(0.0202)\end{array}$ & $\begin{array}{c}-0.0336^{* *} \\
(0.0199)\end{array}$ & 0.1599 \\
\hline Parent & $\begin{array}{c}0.0161 \\
(0.0256)\end{array}$ & $\begin{array}{l}-0.0093 \\
(0.0259)\end{array}$ & $\begin{array}{c}-0.0421^{* *} \\
(0.0216)\end{array}$ & $\begin{array}{c}-0.0777^{* * *} \\
(0.0221)\end{array}$ & 0.7764 \\
\hline Single, no child & $\begin{array}{l}-0.0188 \\
(0.0228)\end{array}$ & $\begin{array}{l}-0.0229 \\
(0.0229)\end{array}$ & $\begin{array}{c}0.0012 \\
(0.0191)\end{array}$ & $\begin{array}{c}0.0207 \\
(0.0194)\end{array}$ & 0.1506 \\
\hline Single, parent & $\begin{array}{c}0.0167 \\
(0.0189)\end{array}$ & $\begin{array}{c}0.0138 \\
(0.0186)\end{array}$ & $\begin{array}{c}0.0235^{*} \\
(0.0153)\end{array}$ & $\begin{array}{c}0.0078 \\
(0.0149)\end{array}$ & 0.0764 \\
\hline
\end{tabular}

${ }^{*} p<0.10,{ }^{* *} p<0.05,{ }^{* * *} p<0.01$ (one-tailed)

Notes: Estimations are based on OLS on equation (1), including all controls from Table III and municipalspecific fixed effects. The 1967-cohort is the omitted reference category, while children born in 1968 and 1969 are placebo cohorts. The outcome variables are defined in Section V. Reported treatment effects are per child care place (TT parameter); ITT/TT $=.1785$ (i.e. the increase in child care coverage following the reform in the treatment group relative to the comparison group). The sample consists of 499,026 children from the birth cohorts 1967-1976. Phase-in-cohorts are born 1970-1972, and post-reform cohorts are born 1973-1976. Standard errors in parentheses are robust to within family clustering and heteroskedasticity. 


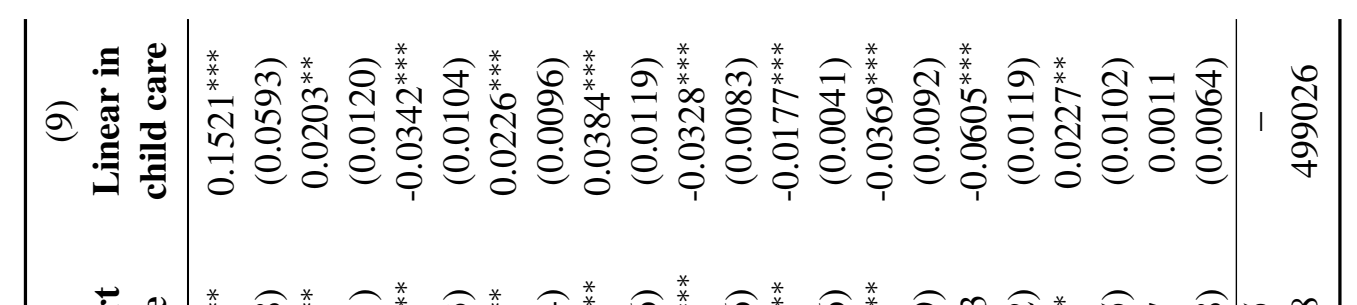

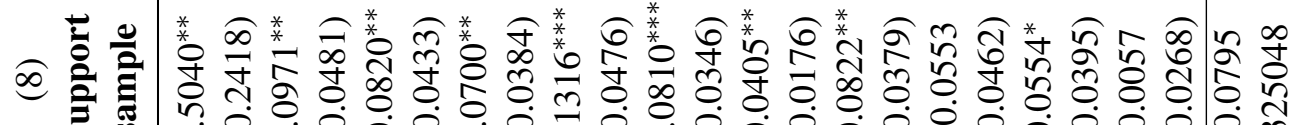

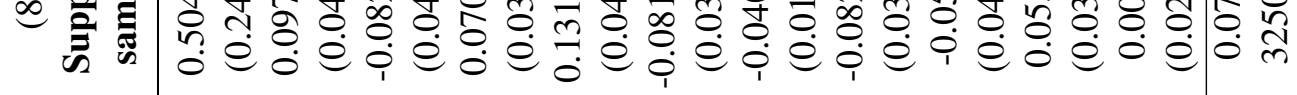

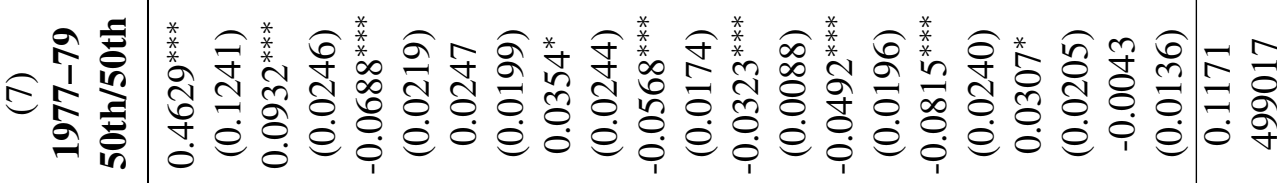

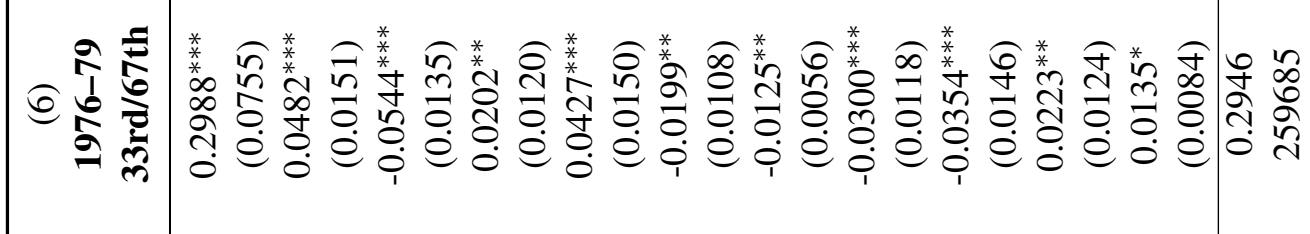

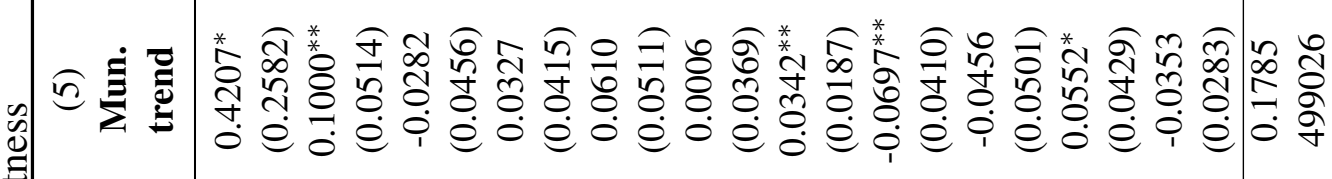

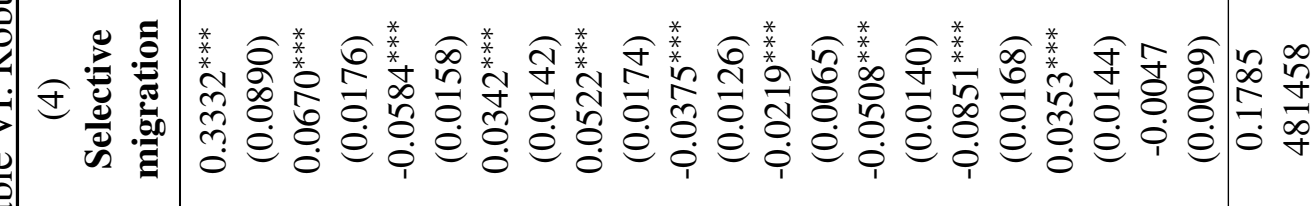

党

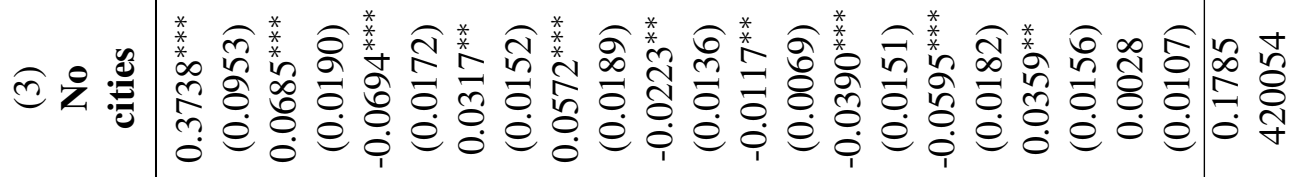

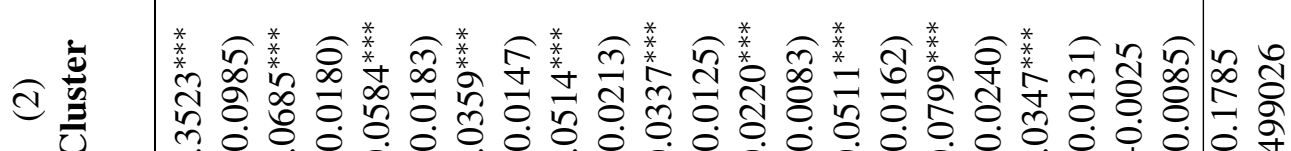

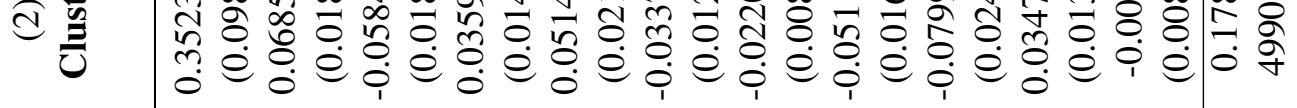

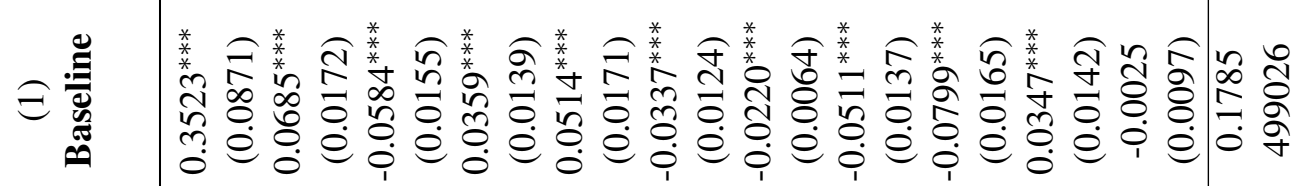

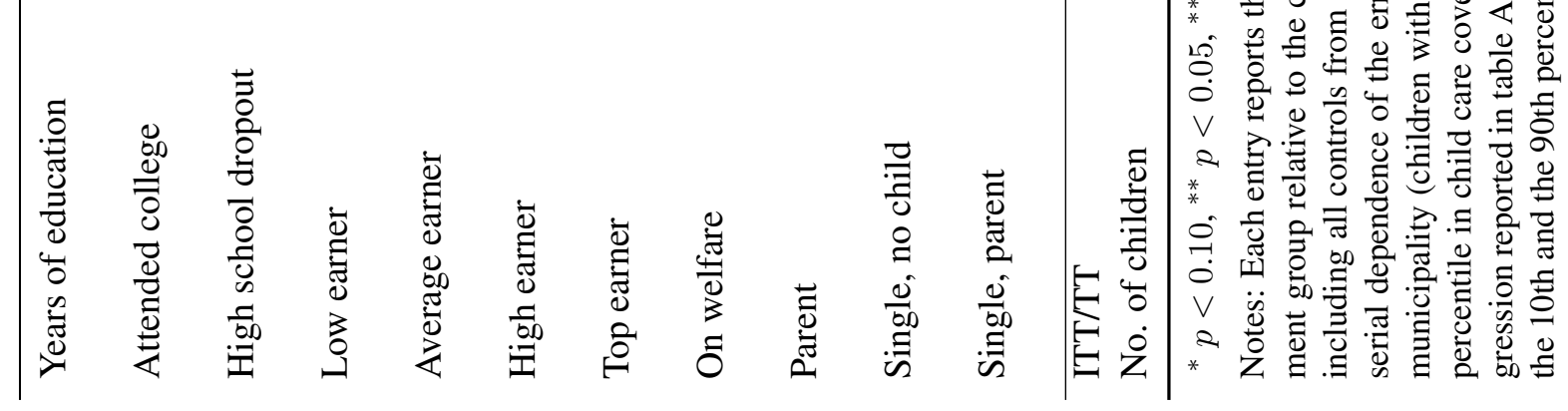

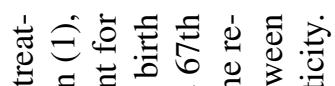
o

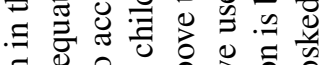

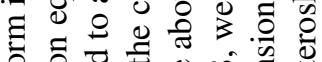

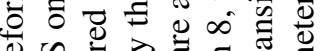
记 巳 on 0 0

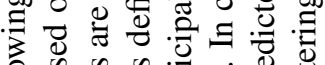

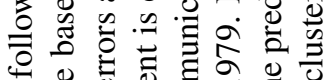
0 吼

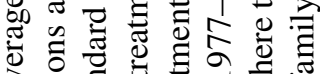

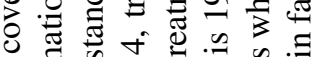

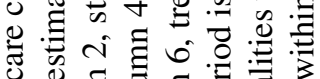

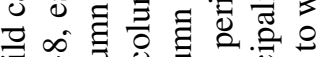

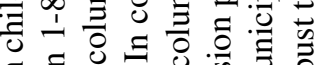

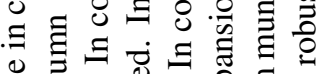

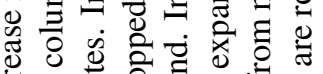

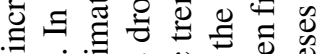

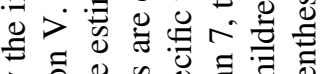

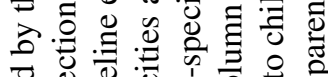
为

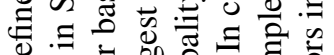

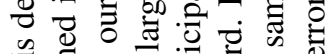
-

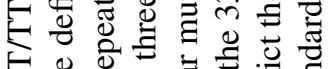

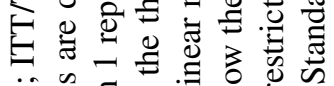

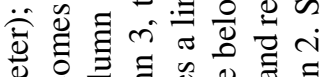

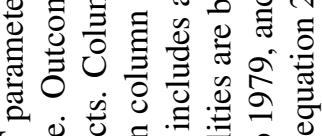

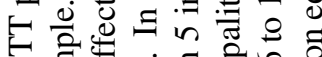

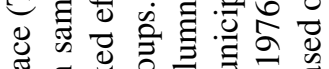

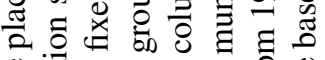
氜

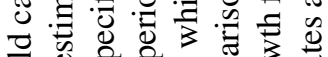
oิ 过

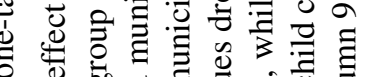

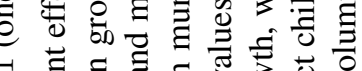

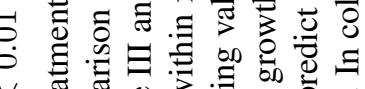

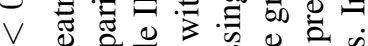
* * 
Table VII: Family-specific fixed effects: Education and earnings

\begin{tabular}{|c|c|c|c|c|c|}
\hline & $\begin{array}{l}\text { (1) } \\
\text { TT }\end{array}$ & $\begin{array}{l}(2) \\
\text { ITT }\end{array}$ & $\begin{array}{c}(3) \\
\text { SE(ITT) }\end{array}$ & $\begin{array}{c}\text { (4) } \\
\text { Controls }\end{array}$ & $\begin{array}{c}(5) \\
\text { Fam. FE }\end{array}$ \\
\hline \multirow{3}{*}{ Years of education } & 0.1538 & 0.0275 & 0.0229 & No & No \\
\hline & $0.1870^{*}$ & $0.0334^{*}$ & 0.0208 & Yes & No \\
\hline & $0.1685^{*}$ & $0.0301^{*}$ & 0.0231 & Yes & Yes \\
\hline \multirow[t]{3}{*}{ Attended college } & $0.0404^{*}$ & $0.0072^{*}$ & 0.0045 & No & No \\
\hline & $0.0444^{* *}$ & $0.0079^{* *}$ & 0.0041 & Yes & No \\
\hline & $0.0530^{* *}$ & $0.0095^{* *}$ & 0.0047 & Yes & Yes \\
\hline \multirow[t]{3}{*}{ High school dropout } & -0.0161 & -0.0029 & 0.0040 & No & No \\
\hline & -0.0255 & -0.0045 & 0.0038 & Yes & No \\
\hline & -0.0197 & -0.0035 & 0.0044 & Yes & Yes \\
\hline \multirow[t]{3}{*}{ Low earner } & -0.0151 & -0.0027 & 0.0035 & No & No \\
\hline & -0.0157 & -0.0028 & 0.0034 & Yes & No \\
\hline & -0.0114 & -0.0020 & 0.0041 & Yes & Yes \\
\hline \multirow[t]{3}{*}{ Average earner } & $0.0496^{* *}$ & $0.0089^{* *}$ & 0.0044 & No & No \\
\hline & $0.0406^{* *}$ & $0.0073^{* *}$ & 0.0042 & Yes & No \\
\hline & $0.0396^{*}$ & $0.0071^{*}$ & 0.0050 & Yes & Yes \\
\hline \multirow[t]{3}{*}{ High earner } & -0.0058 & -0.0010 & 0.0032 & No & No \\
\hline & -0.0109 & -0.0020 & 0.0030 & Yes & No \\
\hline & -0.0079 & -0.0014 & 0.0036 & Yes & Yes \\
\hline \multirow[t]{3}{*}{ Top earner } & $-0.0274^{* * *}$ & $-0.0049^{* * *}$ & 0.0016 & No & No \\
\hline & $-0.0284^{* * *}$ & $-0.0051^{* * *}$ & 0.0016 & Yes & No \\
\hline & $-0.0220^{* *}$ & $-0.0039^{* *}$ & 0.0019 & Yes & Yes \\
\hline \multirow[t]{3}{*}{ On welfare } & $-0.0448^{* *}$ & $-0.0080^{* *}$ & 0.0035 & No & No \\
\hline & $-0.0454^{* * *}$ & $-0.0081^{* * *}$ & 0.0034 & Yes & No \\
\hline & -0.0256 & -0.0046 & 0.0041 & Yes & Yes \\
\hline \multirow[t]{3}{*}{ Parent } & $-0.0836^{* * *}$ & $-0.0149^{* * *}$ & 0.0041 & No & No \\
\hline & $-0.0741^{* * *}$ & $-0.0132^{* * *}$ & 0.0040 & Yes & No \\
\hline & $-0.0665^{* * *}$ & $-0.0119^{* * *}$ & 0.0048 & Yes & Yes \\
\hline \multirow[t]{3}{*}{ Single, no child } & $0.0379^{* *}$ & $0.0068^{* *}$ & 0.0035 & No & No \\
\hline & $0.0315^{*}$ & $0.0056^{*}$ & 0.0035 & Yes & No \\
\hline & $0.0486^{* *}$ & $0.0087^{* *}$ & 0.0042 & Yes & Yes \\
\hline \multirow[t]{3}{*}{ Single, parent } & -0.0015 & -0.0003 & 0.0024 & No & No \\
\hline & 0.0001 & 0.0000 & 0.0024 & Yes & No \\
\hline & 0.0020 & 0.0004 & 0.0029 & Yes & Yes \\
\hline
\end{tabular}

${ }^{*} p<0.10,{ }^{* *} p<0.05,{ }^{* * *} p<0.01$ (one-tailed)

Notes: Estimations are based on OLS on equation (1), with and without controls and family-specific fixed effects. The controls are listed in Table III. The outcomes variable are defined in Section V. The sample consists of 286,835 children from birth cohorts 1967-1976, who belong to families with siblings from at least two of the three groups of cohorts: pre-reform, phase-in group, and post-reform. Mean refers to the pre-reform means in the treatment group. ITT/TT $=.1785$ (i.e. the increase in child care coverage following the reform in the treatment group relative to the comparison group). Standard errors are robust to within family clustering and heteroskedasticity. 
Table VIII: Subsample results by gender and mother's education

\begin{tabular}{|c|c|c|c|c|c|}
\hline & (1) & \multirow{2}{*}{\multicolumn{2}{|c|}{$\begin{array}{l}(2) \\
\text { - Child sex - }\end{array}$}} & \multirow{2}{*}{\multicolumn{2}{|c|}{$\begin{array}{l}(4) \\
- \text { Mother's education - }\end{array}$}} \\
\hline & \multirow[b]{2}{*}{ Full sample } & & & & \\
\hline & & \multicolumn{2}{|c|}{ Boys Girls } & High school & Not high school \\
\hline \multirow[t]{2}{*}{ Years of education } & $0.3523^{* * *}$ & $0.3801^{* * *}$ & $0.3208^{* * *}$ & 0.1161 & $0.4188^{* * *}$ \\
\hline & $(0.0871)$ & $(0.1204)$ & $(0.1251)$ & $(0.2102)$ & $(0.0960)$ \\
\hline \multirow[t]{2}{*}{ Attended college } & $0.0685^{* * *}$ & $0.0690^{* * *}$ & $0.0676^{* * *}$ & 0.0184 & $0.0779^{* * *}$ \\
\hline & $(0.0172)$ & $(0.0235)$ & $(0.0251)$ & $(0.0392)$ & $(0.0194)$ \\
\hline \multirow[t]{2}{*}{ High school dropout } & $-0.0584^{* * *}$ & $-0.0696^{* * *}$ & $-0.0452^{* *}$ & -0.0118 & $-0.0712^{* * *}$ \\
\hline & $(0.0155)$ & $(0.0219)$ & $(0.0218)$ & $(0.0251)$ & $(0.0185)$ \\
\hline \multirow[t]{2}{*}{ Low earner } & $0.0359^{* * *}$ & 0.0019 & $0.0696^{* * *}$ & $0.0479^{* *}$ & $0.0386^{* * *}$ \\
\hline & $(0.0139)$ & $(0.0170)$ & $(0.0222)$ & $(0.0291)$ & $(0.0159)$ \\
\hline \multirow[t]{2}{*}{ Average earner } & $0.0514^{* * *}$ & 0.0175 & $0.0844^{* * *}$ & 0.0314 & $0.0648^{* * *}$ \\
\hline & $(0.0171)$ & $(0.0210)$ & $(0.0269)$ & $(0.0370)$ & $(0.0194)$ \\
\hline \multirow[t]{2}{*}{ High earner } & $-0.0337^{* * *}$ & -0.0256 & $-0.0441^{* * *}$ & $-0.0451^{*}$ & -0.0153 \\
\hline & $(0.0124)$ & $(0.0216)$ & $(0.0113)$ & $(0.0336)$ & $(0.0132)$ \\
\hline \multirow[t]{2}{*}{ Top earner } & $-0.0220^{* * *}$ & $-0.0227^{* *}$ & $-0.0222^{* * *}$ & $-0.0320^{*}$ & $-0.0108^{* *}$ \\
\hline & $(0.0064)$ & $(0.0116)$ & $(0.0049)$ & $(0.0198)$ & $(0.0064)$ \\
\hline \multirow[t]{2}{*}{ On welfare } & $-0.0511^{* * *}$ & $-0.0352^{* *}$ & $-0.0657^{* * *}$ & $-0.0694^{* * *}$ & $-0.0468^{* * *}$ \\
\hline & $(0.0137)$ & $(0.0156)$ & $(0.0228)$ & $(0.0274)$ & $(0.0159)$ \\
\hline \multirow[t]{2}{*}{ Parent } & $-0.0799^{* * *}$ & $-0.0487^{* *}$ & $-0.1141^{* * *}$ & $-0.0702^{* *}$ & $-0.0618^{* * *}$ \\
\hline & $(0.0165)$ & $(0.0248)$ & $(0.0216)$ & $(0.0380)$ & $(0.0185)$ \\
\hline \multirow[t]{2}{*}{ Single, no child } & $0.0347^{* * *}$ & 0.0171 & $0.0532^{* * *}$ & 0.0129 & $0.0315^{* *}$ \\
\hline & $(0.0142)$ & $(0.0225)$ & $(0.0172)$ & $(0.0332)$ & $(0.0158)$ \\
\hline \multirow[t]{2}{*}{ Single, parent } & -0.0025 & 0.0120 & -0.0175 & $-0.0344^{* *}$ & 0.0065 \\
\hline & $(0.0097)$ & $(0.0099)$ & $(0.0168)$ & $(0.0203)$ & $(0.0112)$ \\
\hline No. of children & 499,026 & 253,752 & 245,274 & 101,879 & 397,147 \\
\hline
\end{tabular}

${ }^{*} p<0.10,{ }^{* *} p<0.05,{ }^{* * *} p<0.01$ (one-tailed)

Estimations are based on OLS on equation (1) separately for each subsample, with controls listed in Table III and municipal-specific fixed effects. Each entry reports the treatment effect per child care place (TT parameter) for the subsample assuming equal take-up of the child care places created by the reform; ITT/TT $=.1785$ (i.e. the increase in child care coverage following the reform in the treatment group relative to the comparison group). Outcomes are defined in Section V. Standard errors in parentheses are robust to within family clustering and heteroskedasticity. 
Table IX: Mechanisms: Family size, mother's education and maternal employment

\begin{tabular}{lcccc}
\hline & $(1)$ & $(2)$ & $(3)$ & $(4)$ \\
& TT & ITT & SE(ITT) & Mean \\
\hline Family size & $0.1003^{* * *}$ & $0.0179^{* * *}$ & 0.0060 & 2.995 \\
Mother's education & -0.0051 & -0.0009 & 0.0061 & 10.15 \\
Maternal employment & & & & \\
- Low earner & $-0.0431^{* * *}$ & $-0.0077^{* * *}$ & 0.0025 & 0.1190 \\
- Average earner & $0.0443^{* * *}$ & $0.0079^{* * *}$ & 0.0015 & 0.0373 \\
\hline
\end{tabular}

${ }^{*} p<0.10,{ }^{* *} p<0.05,{ }^{* * *} p<0.01$ (one-tailed)

Notes: The sample consists of 318,367 mothers of the 499,026 children from cohorts born in 1967-1976. ITT/TT $=.1785$ (i.e. the increase in child care coverage following the reform in the treatment group relative to the comparison group). Standard errors are clustered on the mother. Maternal employment: Maternal employment status is determined based on average earnings over the years the child is between 3 and 6 years old. Estimations are based on OLS on the equation in footnote 26. Family size and mother's education: Estimations are based on OLS on equation (1), with controls listed in Table III and municipal-specific fixed effects. Mother's education is measured when the child is 16 years old. Family size is measured in 2006. Standard errors are robust to within family clustering and heteroskedasticity.

Table X: Descriptive statistics: Quality of child care

\begin{tabular}{lcccc}
\hline & $\mathbf{1 9 7 5}$ & $\mathbf{1 9 7 7}$ & $\mathbf{1 9 7 9}$ & $\mathbf{1 9 8 1}$ \\
\hline Treatment & & & & \\
Children/teacher & 16.67 & 18.78 & 19.18 & 18.12 \\
Children/employee & 6.80 & 8.48 & 9.43 & 8.99 \\
No. of institutions & 520 & 988 & 1,582 & 1,794 \\
& & & & \\
\hline Comparison & 18.82 & 17.40 & 17.69 & 17.52 \\
Children/teacher & 7.49 & 7.49 & 8.13 & 8.32 \\
Children/employee & 360 & 481 & 712 & 960 \\
No. of institutions & & & & \\
\hline
\end{tabular}




\section{Figures}

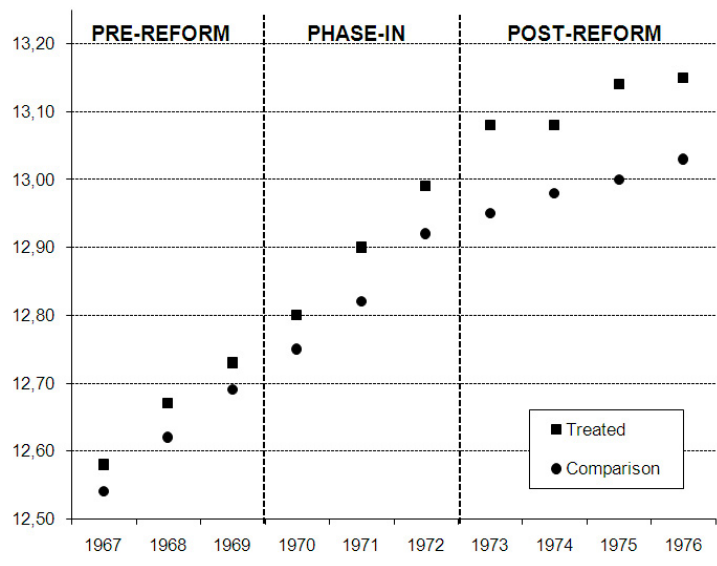

(a) Years of education: Cohort means

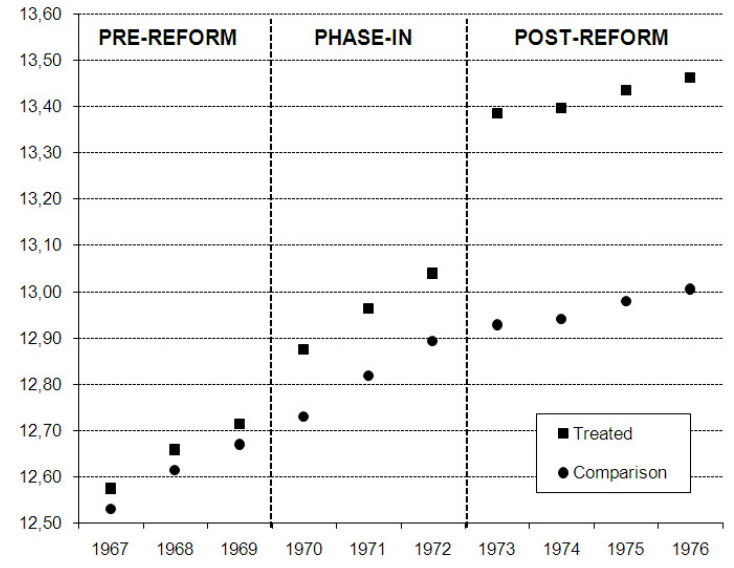

(b) Years of education: Predicted effect

Figure I: Unconditional cohort means for years of education in 2006 by treatment and comparison group for cohorts born 1967-1976, and predicted reform effect per child care place.

Notes: Predicted reform effect is generated from estimation of equation (1) without controls. As discussed in Section IV, to arrive at the reform effects per child care place, the parameters $\gamma_{2}$ and $\theta$ are divided by the probability of treatment (i.e. the increase in child care coverage following the reform in the treatment group relative to the comparison group).

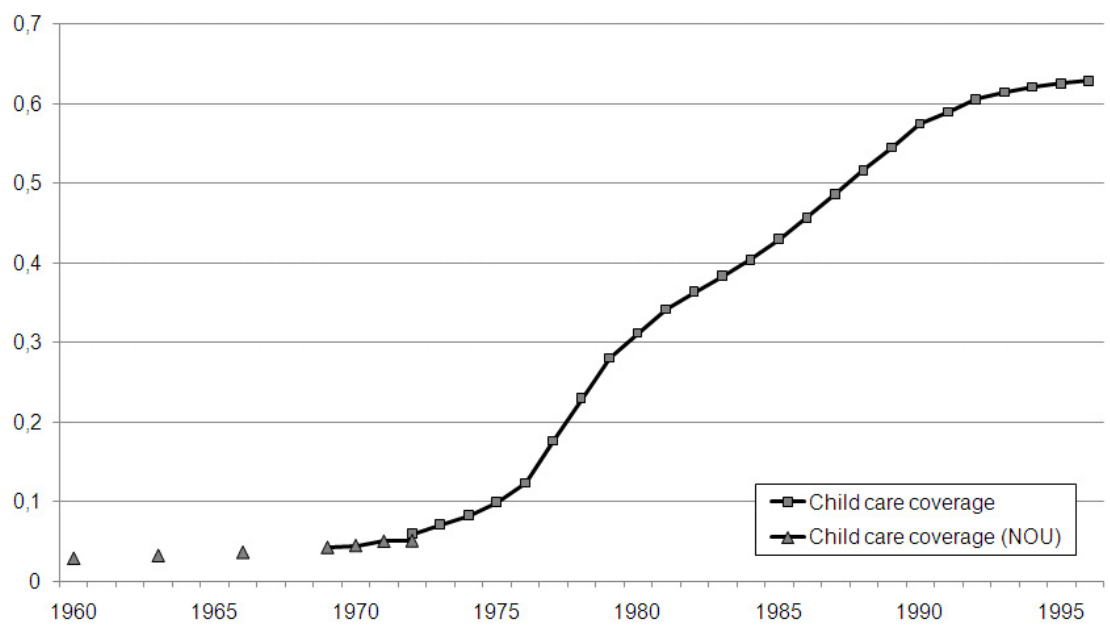

Figure II: Child care coverage rate in Norway 1960-1996 for children 3-6 years old. Sources: Administrative data for 1972-1996. Data for 1960-1972 from NOU (1972), Table II.1. 


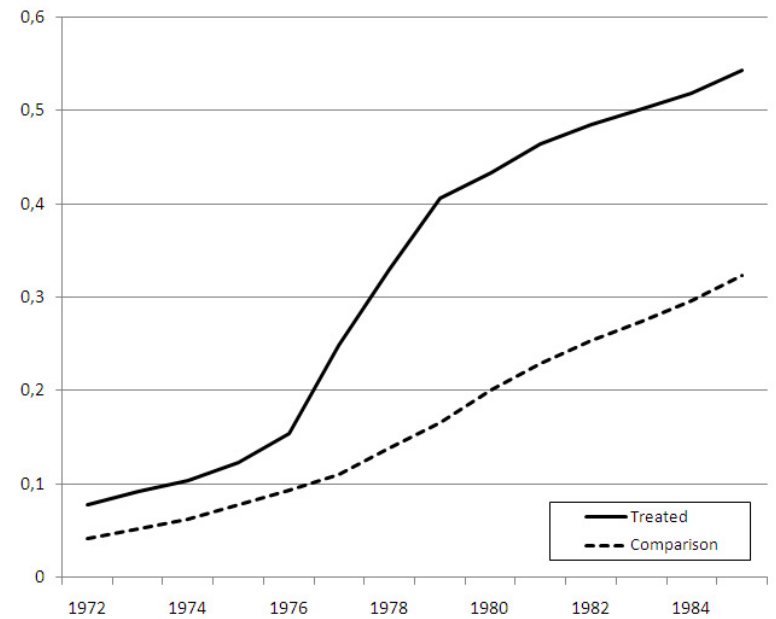

Figure III: Child care coverage rates 1972-1985 for 3-6 year olds in treatment and comparison municipalities.

Notes: Treatment (comparison) municipalities are above (below) the median in child care coverage growth from 1976 to 1979. 


\section{Appendix A}

Table A1: Control variables.

\begin{tabular}{lcccc}
\hline & $(1)$ & $(2)$ & $(3)$ & $(4)$ \\
& TT & ITT & SE(ITT) & Mean \\
\hline Male & 0.0187 & 0.0033 & 0.0034 & 0.507 \\
No. of older siblings & -0.0052 & -0.0009 & 0.0052 & 2.133 \\
Mother's age at first birth & 0.0455 & 0.0081 & 0.0128 & 23.33 \\
Father's age at first birth & 0.011 & 0.0020 & 0.0149 & 26.56 \\
Mother's edu. when child 2 y.o. & $-0.1047^{*}$ & $-0.0187^{*}$ & 0.0118 & 9.662 \\
Father's edu. when child 2 y.o. & $-0.1624^{*}$ & $-0.0290^{*}$ & 0.0159 & 10.37 \\
Immigrant & 0.0106 & 0.0019 & 0.0015 & 0.0566 \\
Relocated & $0.0337^{* * *}$ & $0.0060^{* * *}$ & 0.0017 & 0.0358 \\
\hline
\end{tabular}

Estimations are based on OLS on equation (??), with controls listed in Table ?? and municipal-specific fixed effects, excluding the dependent variable from the set of controls. ITT/TT $=.1785$ (i.e. the increase in child care coverage following the reform in the treatment group relative to the comparison group). Mean refers to the pre-reform means in the treatment group. Standard errors are robust to within family clustering and heteroskedasticity. 
Table A2: Descriptive statistics for treatment and comparison municipalities in 1976

\begin{tabular}{|c|c|c|c|c|}
\hline \multirow[b]{2}{*}{ Child care/maternal employment rate } & \multicolumn{2}{|c|}{ Treatment } & \multicolumn{2}{|c|}{ Comparison } \\
\hline & 0.2471 & {$[0.4596]$} & 0.3542 & {$[0.6213]$} \\
\hline Years of education, males & 9.2256 & {$[0.5514]$} & 9.2174 & [0.4699] \\
\hline- , females & 8.8198 & {$[0.3820]$} & 8.7672 & [0.3313] \\
\hline Earnings, males & 0.3917 & {$[0.0762]$} & 0.4081 & {$[0.0734]$} \\
\hline- , females & 0.1080 & {$[0.0349]$} & 0.1121 & [0.0321] \\
\hline Labor force part., males & 0.8324 & {$[0.0591]$} & 0.8367 & {$[0.0665]$} \\
\hline- , females & 0.2919 & {$[0.0844]$} & 0.2997 & [0.0813] \\
\hline \multicolumn{5}{|l|}{ Expenditure (1000 NOK/capita) } \\
\hline Total & 6.2377 & [1.8918] & 5.9132 & [1.4921] \\
\hline Primary school & 1.5716 & {$[0.6981]$} & 1.4521 & [0.5904] \\
\hline \multicolumn{5}{|l|}{ Revenue (1000 NOK/capita) } \\
\hline Ear marks, total & 3.702 & [1.4167] & 3.5522 & [1.1317] \\
\hline- , primary school & 0.5706 & {$[0.2165]$} & 0.5684 & {$[0.2348]$} \\
\hline Fees, total & 0.8102 & {$[0.5852]$} & 0.6826 & [0.4147] \\
\hline- , primary school & 0.0056 & {$[0.0090]$} & 0.0063 & [0.0117] \\
\hline Taxes & 2.4635 & {$[0.6825]$} & 2.4641 & [0.7459] \\
\hline \multicolumn{5}{|l|}{ Geography } \\
\hline In densely populated areas & 0.4049 & {$[0.2915]$} & 0.4827 & [0.2979] \\
\hline Ave. distance to zone center & 0.8876 & {$[0.7789]$} & 0.7732 & [0.6788] \\
\hline - to neighboring center & 3.7768 & {$[2.6130]$} & 3.4297 & [2.8039] \\
\hline \multicolumn{5}{|l|}{ Population } \\
\hline Total & 9846 & {$[36400]$} & 9476 & [13267] \\
\hline Married & 0.4664 & {$[0.0277]$} & 0.4618 & {$[0.0346]$} \\
\hline Divorced & 0.0144 & {$[0.0081]$} & 0.0153 & {$[0.0080]$} \\
\hline Immigrant & 0.0098 & {$[0.0096]$} & 0.0095 & {$[0.0086]$} \\
\hline 0 to 6 years old & 0.1077 & {$[0.0177]$} & 0.1141 & {$[0.0177]$} \\
\hline 7 to 10 years old & 0.0673 & [0.0099] & 0.0708 & [0.0097] \\
\hline 11 to 18 years old & 0.1293 & {$[0.0127]$} & 0.1314 & {$[0.0133]$} \\
\hline Females: 19 to 35 years old & 0.1021 & {$[0.0187]$} & 0.1082 & {$[0.0170]$} \\
\hline -: 36 to 55 years old & 0.1027 & {$[0.0101]$} & 0.1019 & {$[0.0095]$} \\
\hline Males: 19 to 35 years old & 0.1175 & {$[0.0152]$} & 0.1227 & [0.0137] \\
\hline -: 36 to 55 years old & 0.1096 & {$[0.0091]$} & 0.1077 & [0.0092] \\
\hline \multicolumn{5}{|l|}{ Politics } \\
\hline Registered voters & 6480 & {$[26654]$} & 5863 & [8488] \\
\hline- , female & 0.4896 & [0.0169] & 0.4928 & {$[0.0167]$} \\
\hline Election participation & 0.7243 & {$[0.0587]$} & 0.7093 & {$[0.0563]$} \\
\hline- , females & 0.7094 & {$[0.0666]$} & 0.6962 & {$[0.0632]$} \\
\hline Female elected representatives & 0.1521 & {$[0.0807]$} & 0.1394 & {$[0.0635]$} \\
\hline Socialist vote share & 0.3864 & {$[0.1654]$} & 0.4031 & {$[0.1651]$} \\
\hline Socialist mayor & 0.3140 & {$[0.4652]$} & 0.3671 & [0.4832] \\
\hline Female mayor & 0.0097 & {$[0.0981]$} & 0.0145 & [0.1198] \\
\hline
\end{tabular}

${ }^{*} p<0.10,{ }^{* *} p<0.05,{ }^{* * *} p<0.01$ (one-tailed)

Notes: Columns 1-4 report means and standard deviations across treatment and comparison municipalities, not weighted by population size. Columns 5 and 6 report estimates and robust standard errors from an OLS regression with the percentage point increase in child care coverage rate between 1976 and 1979 as the dependent variable. Earnings denotes pensionable income in NOK 100,000. Socialist parties are defined as RV, SV and DNA. Densely populated areas are contiguous zones of at least 200 people where the distance between houses is generally less than 50 meters (400 meters if separated by e.g. parks, rivers or industrial zones). Average distance to zone center is the mean predicted travel distance in $\mathrm{km}$ from a citizen's home to the most populous census area in a contiguous zone of more than 2,000 people within the municipality. Distance to neighboring center is the mean travel distance from the center of a census area to the closest center in another census area within the same economic zone. Standard deviations are in brackets and standard errors are in parentheses. 


\section{Appendix B}

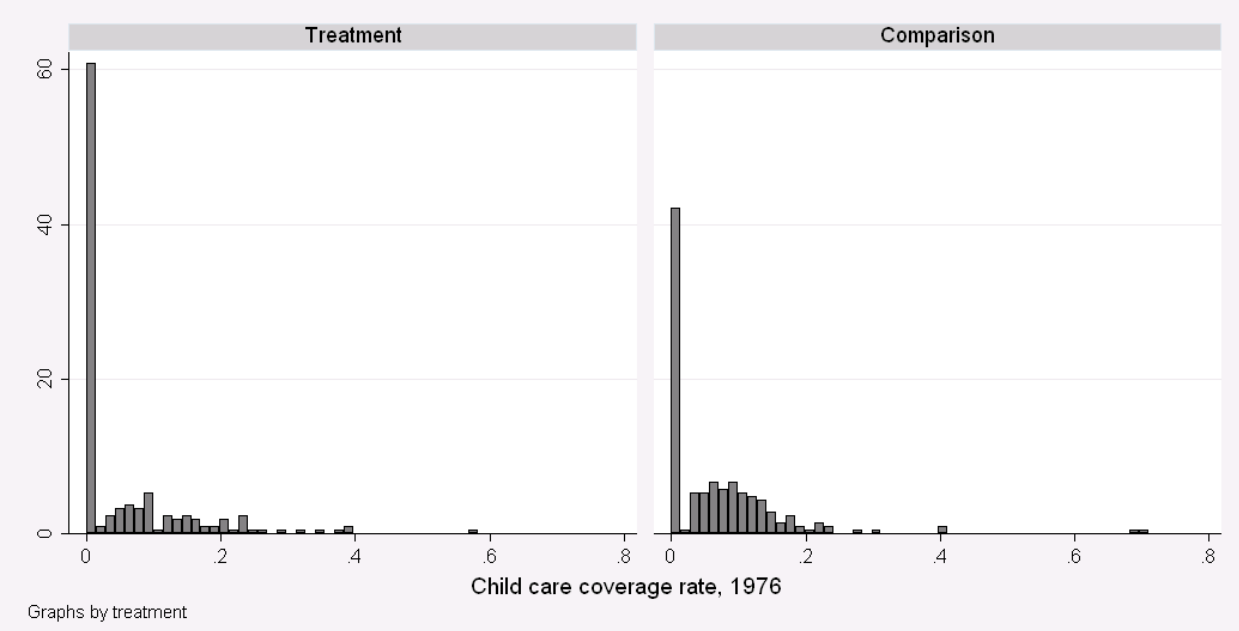

(a) 1976

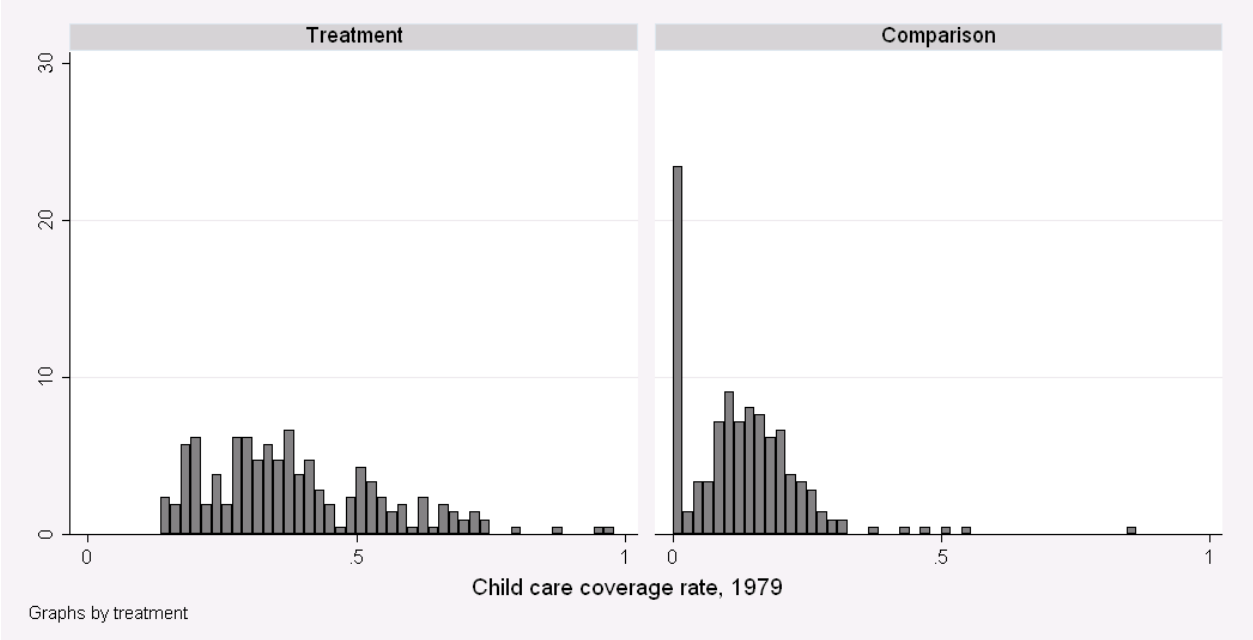

(b) 1979

Figure A1: Distribution of treatment and comparison municipalities by child care coverage rate for 3 to 6 year olds in 1976 (top panel) and 1979 (bottom panel).

Notes: Pre-reform cohorts are born 1967-1969, phase-in-cohorts are born 1970-1972, and post-reform cohorts are born 1973-1976. Treatment (comparison) municipalities are above (below) the median in child care coverage growth from 1976 to 1979. 


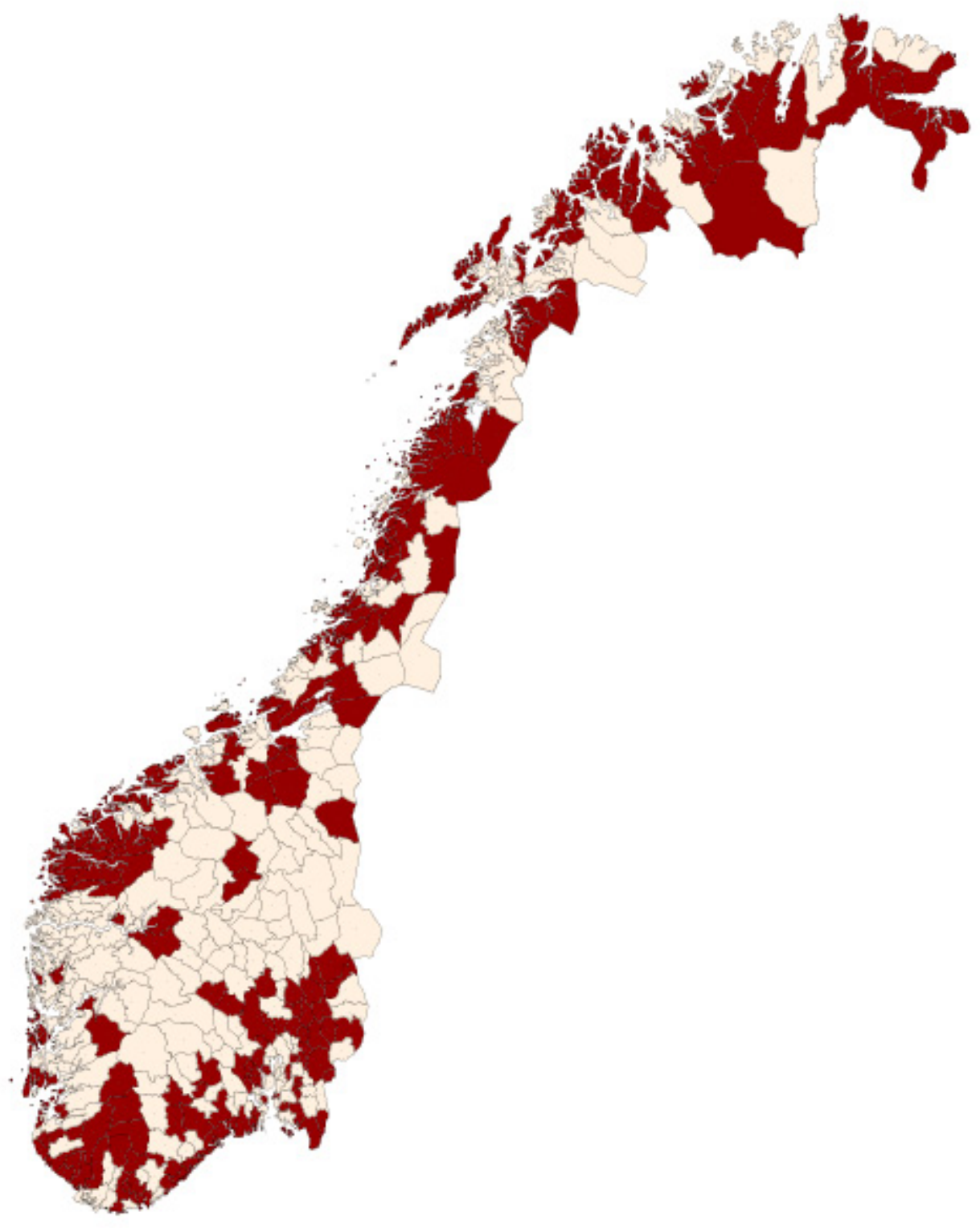

Figure A2: Geographic location of treatment (white) and comparison (dark) municipalities 


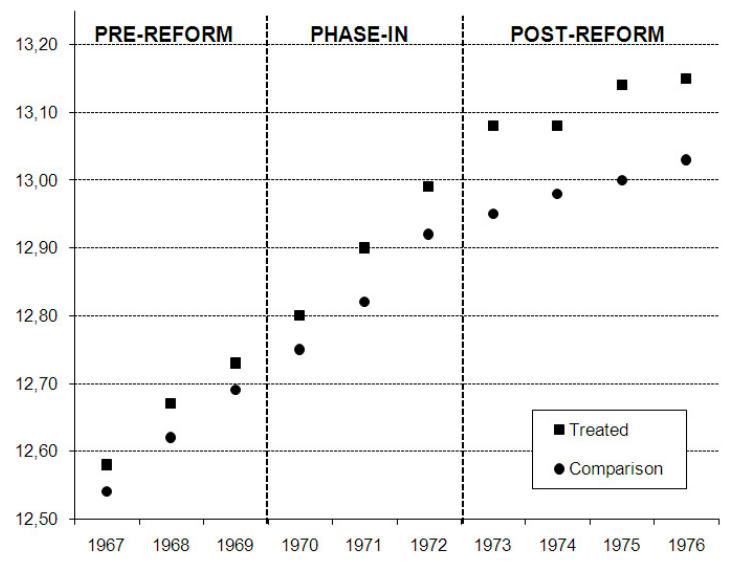

(a) Years of education

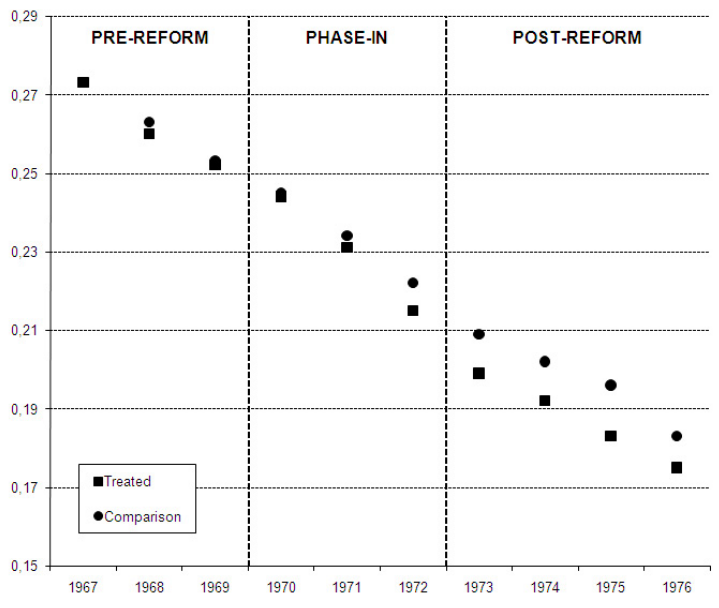

(c) High school dropout

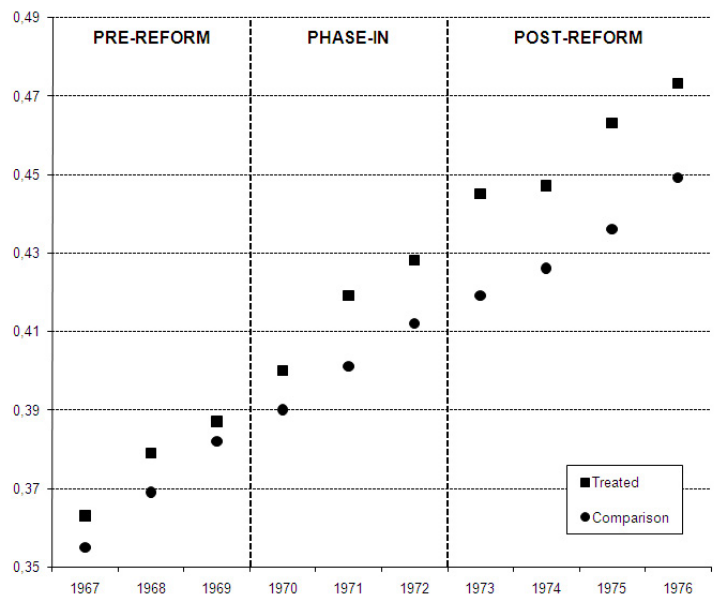

(b) Attended college

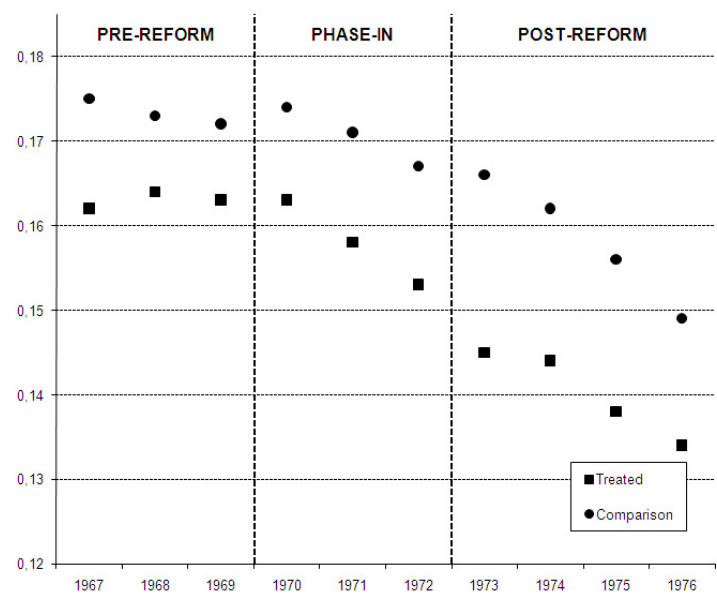

(d) On welfare

Figure A3: Unconditional cohort means for education and welfare dependency for cohorts born 1967-1976 by treatment and comparison group 


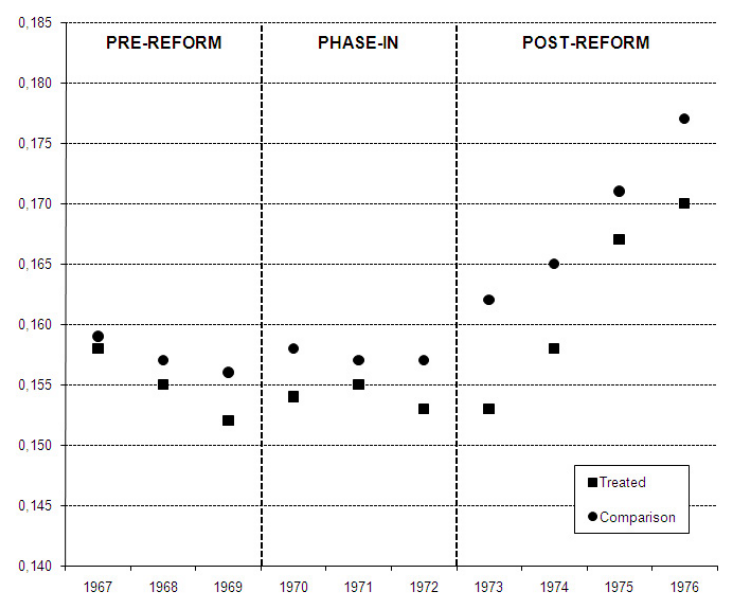

(a) Low earner

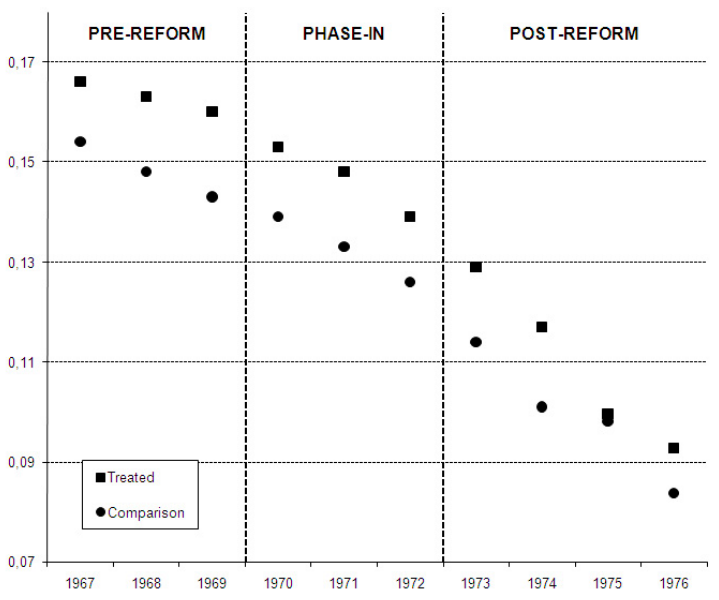

(c) High earner

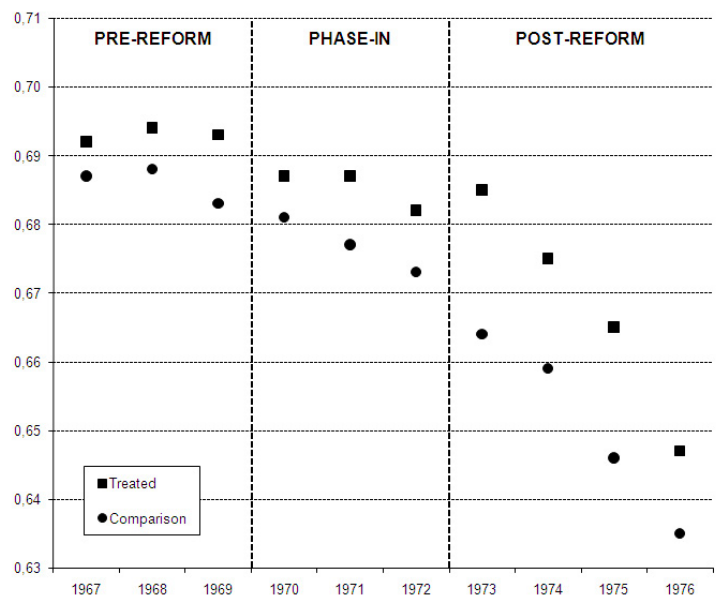

(b) Average earner

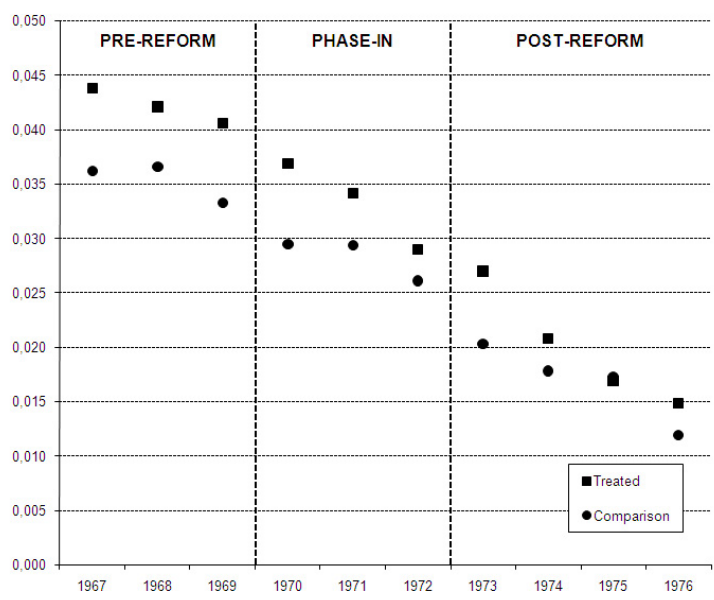

(d) Top earner

Figure A4: Unconditional cohort means for earnings for cohorts born 1967-1976 by treatment and comparison group 


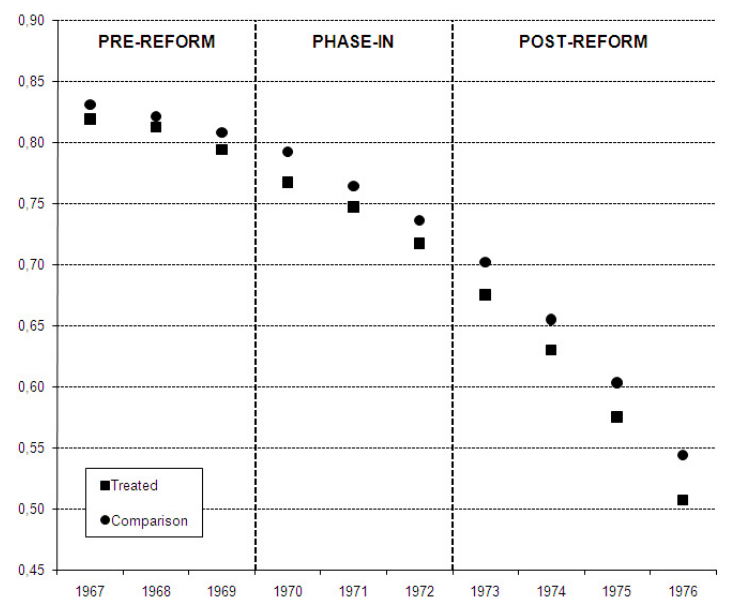

(a) Parent

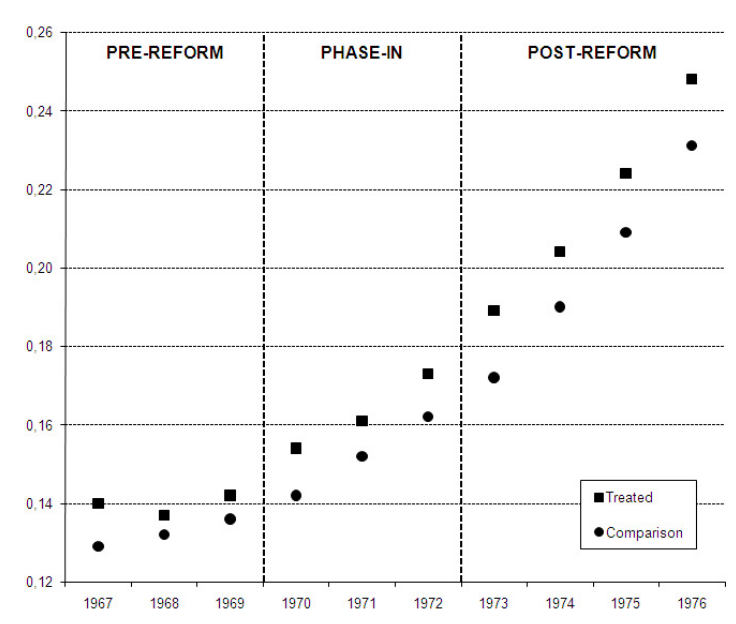

(c) Single, no child

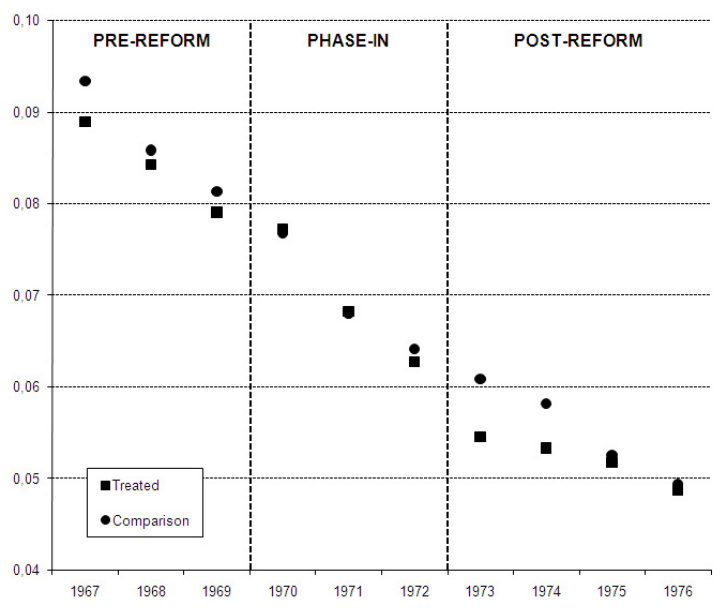

(b) Single, parent 